\title{
Palaeoecology and sedimentology of the Miocene marine and terrestrial deposits in the "Medieval Quarry" on Devínska Kobyla Hill (Vienna Basin)
}

\author{
Daniel PIVKO ${ }^{1, *}$, Natália HUDÁČKOVÁ ${ }^{1}$, Juraj HRABOVSKÝ², Imrich SLÁDEK ${ }^{1}$ and Andrej RUMAN ${ }^{1}$ \\ 1 Comenius University, Faculty of Natural Sciences, Department of Geology and Paleontology, Mlynská dolina, Ilkovičova 6, \\ 84215 Bratislava, Slovakia \\ 2 Slovak Academy of Sciences, Earth Science Institute, Dúbravská cesta 9, 84005 Bratislava, Slovakia
}

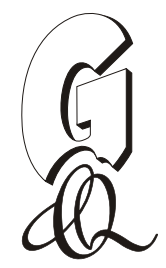

Pivko, D., Hudáčková, N., Hrabovský, J., Sládek, I., Ruman, A., 2017. Palaeoecology and sedimentology of the Miocene marine and terrestrial deposits in the "Medieval Quarry" on Devínska Kobyla Hill (Vienna Basin). Geological Quarterly, 61 (3): 549-568, doi: 10.7306/gq.1357

\begin{abstract}
Dramatic tectonic and sea level changes of the Central Paratethys realm during the Middle Miocene resulted in changes of the coastal and seabed morphology affecting the composition of the marine association and the distribution of the facies along the coast. Three different episodes (marine-terrestrial-marine) in the environmental evolution are interpreted. A lower marine unit (Badenian; Lower Serravallian) reflects organodetrital sedimentation on and around an algal bioherm. Low terrigenous input maërl facies of typical rhodalgal carbonate factory type characterise the top of the algal mound. On the slopes, a rim of rhodechfor facies separated the bioherm from the rest of the bottom which had a seagrass cover. This high-energy rhodechfor carbonate factory is described from the Central Paratethys realm for the first time. It is composed mostly of coralline algae (Mesophyllum, Lithothamnion, Spongites and Lithophyllum), benthic foraminifers (Elphidium crispum, Neoconorbina terquemi, Miniacina sp., Borelis melo), echinoids (cidaroid, spatangoid and diadematoid groups) and bryozoans. Uplift of the Malé Karpaty Mts. resulted in tectonic activity in the vicinity, documented by the presence of clastic dikes and normal faults in the profile studied. Subsequent fluvial and terrestrial sedimentation is represented by regolith, palaeosoil and channel body deposits set discordantly on the top of lagoonal deposits. Finally, the third episode is represented by the Sarmatian transgressive marine sequence, which is characterized by coarse pebbly deposit eroded from an uplifted pre-Neogene basement. The strata studied originated in a warm temperate climate around the Badenian-Sarmatian transition.
\end{abstract}

Key words: rhodechfor, rhodalgal, palaeoecology, sedimentology, Middle Miocene, Central Paratethys.

\section{INTRODUCTION}

Ecological changes in the Central Paratethys realm during the Middle Miocene are reflected in the Vienna Basin tectono-sedimentary record. Various shallow-water depositional environments, developed on the former coast, were affected by sea level oscillations.

The Devínska Kobyla Hill, situated in the Malé Karpaty Mountains (northern Vienna Basin), provides numerous accessible exposures with different lithofacies and faunal assemblages (Hyžný et al., 2012). The Middle Miocene strata exposed here document changes of marginal environments during this time while the overall climate was fairly uniform, reflecting the stable subtropical conditions of the Miocene Climate Optimum (Kvaček et al., 2006).

* Corresponding author, e-mail: pivko@fns.uniba.sk

Received: October 18, 2016; accepted: March 12, 2017; first published online: April 28, 2017
The "Medieval Quarry" outcrop, active mostly in the Middle Ages (Pivko, 2011), lies above the village of Devín. It is situated on the SW hillside of the hill (Fig. 1) at an altitude of 295-325 m, and has been noted by Koutek and Zoubek (1936) and Mišík (1997). Petrographic and historical studies were made by Pivko (2011). This study focuses on detailed sedimentological, micropalaeontological and palaeoecological aspects.

\section{GEOLOGICAL SETTING}

The strata studied in the "Medieval Quarry" belong to the Studienka Fm. which represents the Upper Badenian deposits of the Vienna Basin (Fig. 2; Polák et al., 2011a, b). Lithotypes forming the section studied (breccias, conglomerates, sands, sandstones and red algal limestones) of the Sandberg Mb., represent marginal facies of the basin (Baráth et al., 1994). In the calcareous basal conglomerates of the Sandberg Member cropping out on the western slopes of the Devínska Kobyla Hill, the bioclasts of foraminifers, bryozoans, molluscs, sea urchins, red algae, ostracods and crustaceans have been found (Koutek and Zoubek, 1936). In the overlying sand layers, molluscs, foraminifers and fragments of vertebrates have been recovered (Holec and Sabol, 1996). The carbonates are repre- 


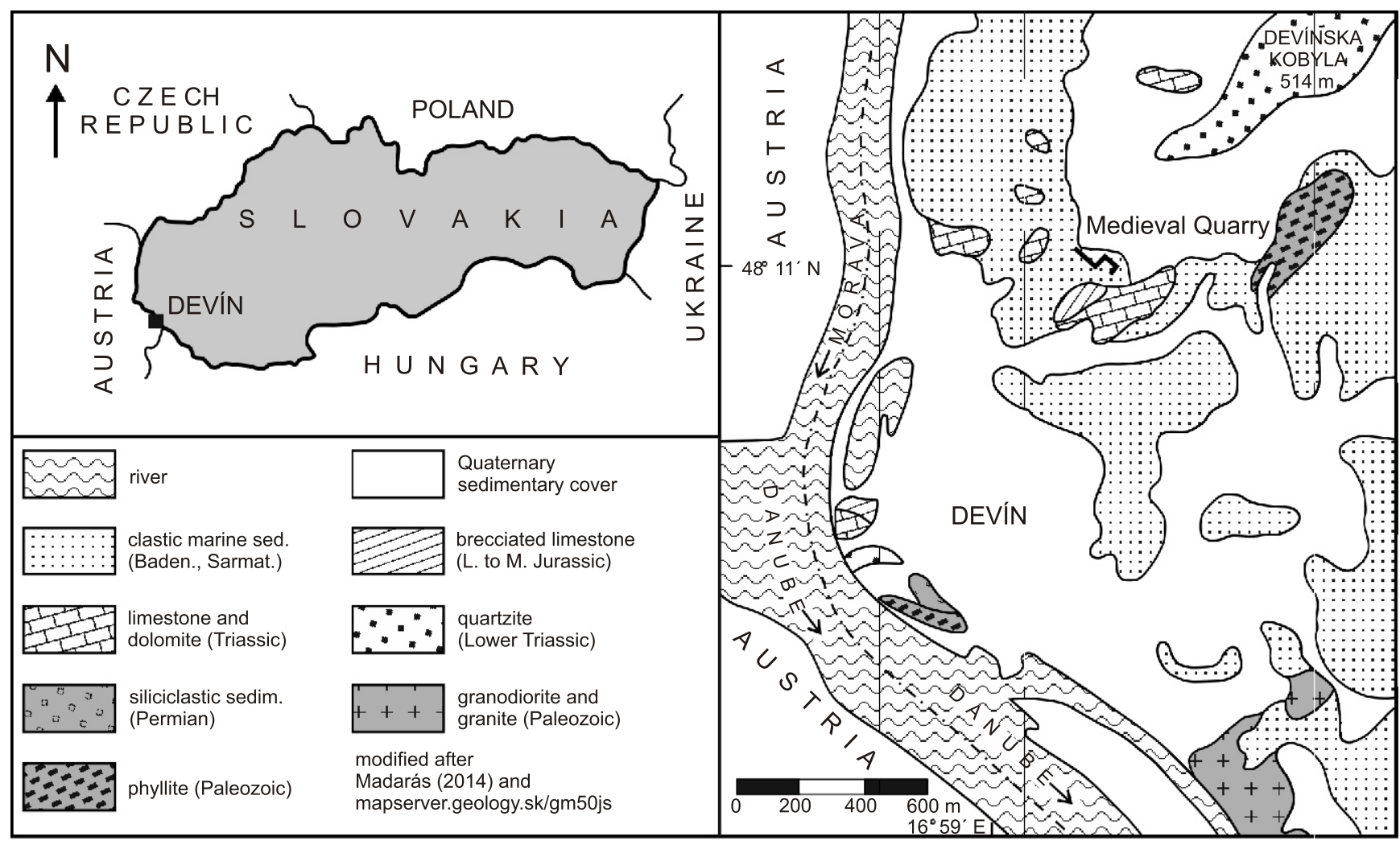

Fig. 1. Geological setting of the "Medieval Quarry"

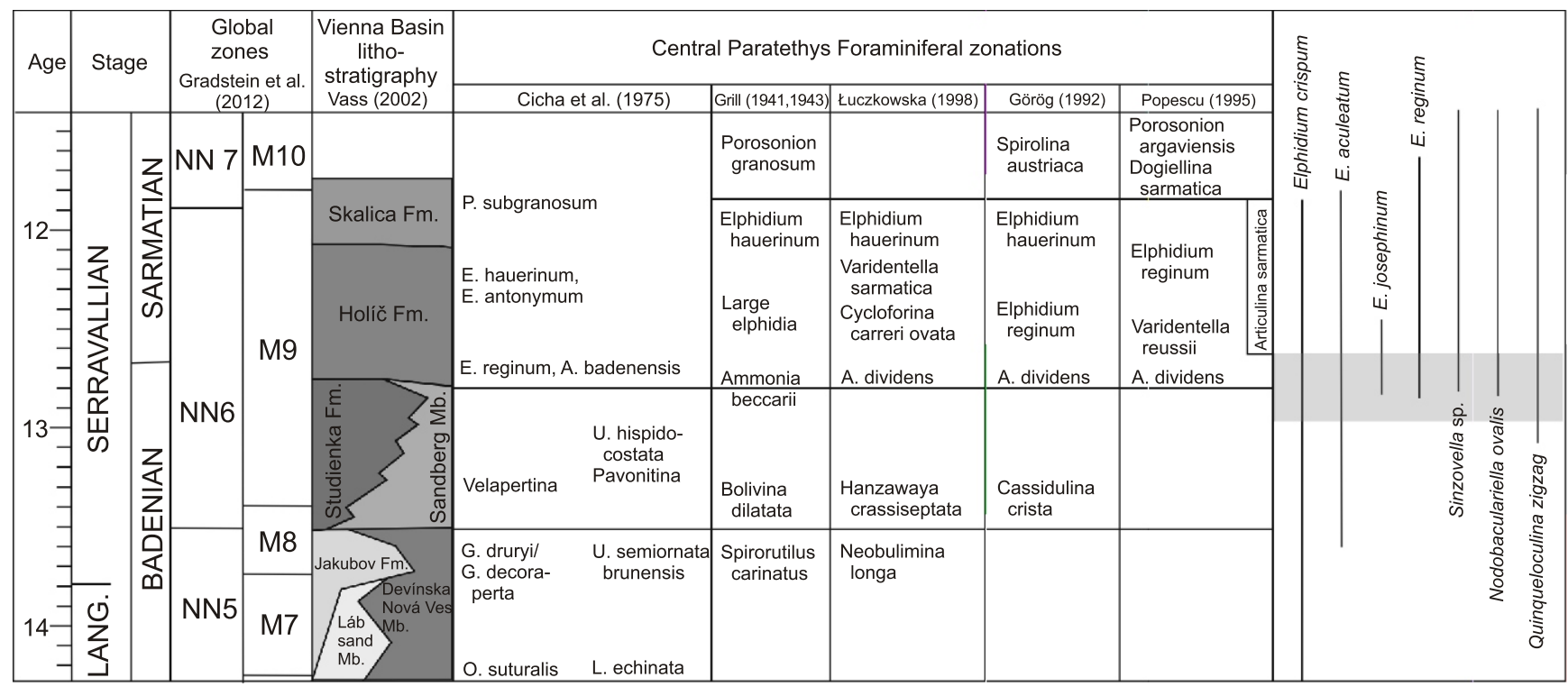

Fig. 2. Stratigraphic correlation chart 
sented by sandy organodetrital and biohermal limestones. Coralline algae - Lithothamnion (as Lithothamnium), Mesophyllum and Lithophyllum (Schaleková, 1969; Schaleková in Švagrovský, 1978) - predominate over bryozoans, molluscs and foraminifers. These limestones are diachronous throughout the Upper Badenian (Polák et al., 2011a, b). The direct basement of the Miocene deposits, according to the geological map, is formed by the Guttenstein Limestone and Ramsau Dolomite formations of Triassic age and brecciated limestone of the Pleš Breccia Fm. of Jurassic age (Polák et al., 2011a, b). The Lower Triassic quartzites of the Lúžna Fm., Lower Paleozoic phyllites and Permian siliciclastic deposits are situated higher upslope on the Devínska Kobyla Hill. The Upper Paleozoic granitoid are situated a little further away (Fig. 1).

Strata of the Studienka Fm. have been associated with a Late Badenian age (e.g., Vass, 2002; Kováč et al., 2007). The biostratigraphy of the Badenian deposits (Fig. 2) and their upper boundary are still subject to debate (e.g., Harzhauser and Piller, 2004a, b; Piller et al., 2007; Hohenegger et al., 2008, 2014 Hudáčková and Zlinská, 2010; Gonera, 2013; Peryt, 2013). Their age was determined on the basis of both foraminiferal assemblages belonging to the Bulimina/Bolivina Zone or CPN9 Velapertina Biozone (Cicha et al., 1975) and nannofossils of the NN6 Zone (Kováčová and Hudáčková, 2009; Jamrich and Halásová, 2010; Hyžný et al., 2012). A numerical age of $\sim 13.58 \mathrm{Ma}$, based on ${ }^{86} \mathrm{Sr} /{ }^{87} \mathrm{Sr}$ ratios, were derived from the deep-water pelites of the Devínska Nová Ves brickyard, placed within the Studienka Fm. (Hudáčková et al., 2003; Kováčová and Hudáčková, 2009) and 13.7-13.2 Ma from the Sandberg locality (Fordinál et al., 2014). Sarmatian deposits have been identified in the vicinity of the Sandberg locality (Földes, 1960 Polák et al., 2011a, b; Hyžný et al., 2012; Bitner et al., 2014). The ${ }^{86} \mathrm{Sr} /{ }^{87} \mathrm{Sr}$ ratio from the uppermost part of the Sandberg section also indicates a Sarmatian age of $12.7 \mathrm{Ma}$ (Fordinál et al., 2014). The age of the Sarmatian transgression and related faunal assemblage turnover (BSE) in the Central Paratethys have been treated by Harzhauser and Piller (2004a, b), Filipescu (2004), Gebhardt et al. (2009), Tóth et al. (2010), Koubová and Hudáčková (2010) and Filipescu et al. (2014), using various approaches.

\section{METHODS}

This study mainly focuses on deposits and their structures, microfacies and petrographic analysis, coralline algae, foraminifera and echinoids. Due to their scarcity, recrystallisation and fragmentation, study of calcareous nannoplankton and molluscs did not yield any relevant results, therefore they were only partially included in the research.

\section{SEDIMENTOLOGY AND PETROGRAPHY}

The abandoned "Medieval Quarry" is about $100 \mathrm{~m}$ across. Exposed faces were studied in terms of grain size, sedimentary structures, petrographic and palaeontological compositions. Individual profiles can be laterally linked to an idealized lithostratigraphic log (Fig. 3). Twenty-five thin sections (Fig. 3) were made throughout the succession from the main lithologies, particularly of limestones. Siliciclastic material such as mono- and polycrystalline quartz, metamorphic rocks with a predominance of phyllosilicates, phyllosilicate flakes, feldspar and feldspar-quartz rocks and other rocks and minerals, further carbonate material such as micrite, microsparite and sparite was distinguished using modal analysis. Coralline algae, molluscs, sea urchins, foraminifers, ostracods, tube-worms and bryozoans were also noted (Fig. 4).

Since the deposits are composed of mixed material, a ternary diagram for hybrid sandstones was used (Zuffa, 1980) with end members: siliciclastic material of non-carbonate extrabasinal origin (NCE), older carbonates of carbonate extrabasinal origin (CE), and fossils and intraclasts of carbonate intrabasinal origin ( $\mathrm{Cl}$; Fig. 5). Extrabasinal material represents sediment derived from the pre-Neogene basement. Siliciclastic and carbonate extrabasinal material was studied using the QFL and QmFLt ternary diagrams for the geotectonic classification of sedimentary grains (Dickinson et al., 1983).

\section{MICROPALAEONTOLOGY}

Coralline algae and echinoids were studied in thin sections using a Amplival Carl Zeiss Jena light microscope. Coralline algae systematics at the genus level followed Braga et al. (1993) and Hrabovský et al. (2015). Determination at a higher taxonomic levels followed Rösler et al. (2016). Palaeoclimatological and palaeoecological interpretations were made on the basis of the high-rank taxa used in the distributional model proposed by Aguirre et al. (2000), where the Mastophoroideae (including among others, Spongites and Hydrolithon) comprise different genera than the Masthoporoideae according to Rösler et al. (2016). Moreover, new subfamilies i.e. the Hydrolithoideae (including Hydrolithon) and the Neogoniolithoideae (with Spongites) were established by Kato and Baba in Kato et al. (2011) and Rösler et al. (2016).

For the purpose of this work, genera and higher level taxa were used, with only Titanoderma pustulatum (Lamouroux) Nägeli being determined at a species level. For the growth form of species and structure determination of rhodoliths, the works of Woelkerling et al. (1993) and Bosence (1983) were followed. Echinoid systematics were based on Kroh and Nebelsick (2010).

For the study of the foraminiferal assemblages, $200 \mathrm{~g}$ of bulk sediment was diluted in $5 \% \mathrm{H}_{2} \mathrm{O}_{2}$, and then sieved using 0.071 and $1 \mathrm{~mm}$ mesh sieves. Up to 250 benthic foraminifera specimens were collected, determined and photographed using an Olympus SZ61 binocular stereomicroscope and a Quanta FEG250 SEM (Fig. 6). Determination of foraminifera was based on Loeblich and Tappan (1992), Cicha et al. (1998) and Holbourn et al. (2013). Due to a lack of planktic foraminifers, biostratigraphic interpretations were based on Grill (1941) and Cicha et al. (1975); stratigraphical ranges of the foraminifers were selected from the works of Papp (1959) and Cicha et al. $(1983,1998)$. A correlation between the Central Paratethys regional stages and the Mediterranean scale, as defined by Piller et al. (2007), Kováč et al. (2007) and Hohenegger et al. (2014), was used (Fig. 2). For samples containing at least 150 specimens of benthic foraminifera, palaeoecological parameters were evaluated on the basis of the presence and dominance of ecologically significant taxa (Fig. 4). Species diversity indices and ternary plots of trophic strategy and wall structure (sensu Murray, 1973, 2006) were used to interpret the raw data (Fig. 7A, B). The depth estimation roughly follows Hohenegger's (2005) coexistence method, using the environmental demands of benthic foraminifers which were derived mostly from Boltovskoy (1976), Boltovskoy and Wright (1976), Hohenegger (2005), Murray (2006) and Spezzaferri et al. (2013). For statistical analysis, PAST software (Hammer et al. 2001) was used. The taphonomy of the foraminiferal assemblages was evaluated according to Holcová $(1997,1999)$. 


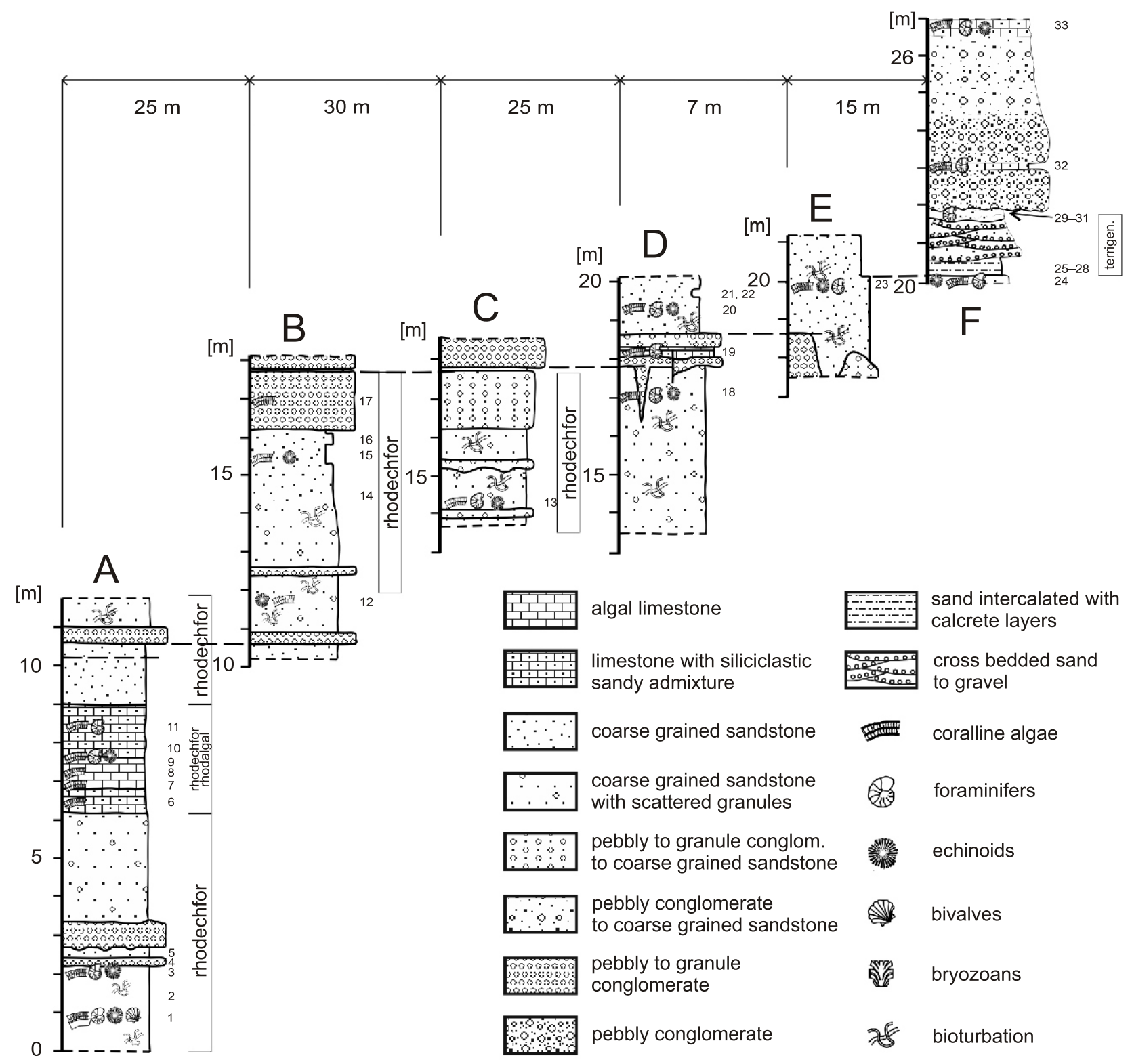

Fig. 3. Composite profile

\section{RESULTS}

\section{SEDIMENTOLOGY AND PETROGRAPHY}

In the composite log studied (Fig. 3), short distance lateral and vertical changes in grain size and in the ratio of siliciclastic material, carbonate material and fossils were identified (Fig. 2). The lower sequence (0-20.1 m; locally $21.1 \mathrm{~m}$; Fig. 3E above the base of the composite profile) consists of a yellowish medium to fine-grained sandstone with locally scattered pebbles up to $2 \mathrm{~cm}$ across. Conglomeratic layers with clasts up to 2 $\mathrm{cm}$ across (rarely up to $10 \mathrm{~cm}$; Fig. 8A), and cream-coloured limestones composed mostly of coralline algae with varied admixtures of clastic material are minor in this interval. The limestones are formed by algal, algal-bryozoan nodules, bryozoan colonies, carbonate clasts covered by algae or drilled by tube worms, sponges and bivalves and algal-tube worm nodules
(Fig. 4A). In the entire profile, bivalve shells and moulds (cardiids, scallops, oysters) are rarely present.

Due to bioturbation, the contacts between beds are often indistinct. Bioturbation is emphasised by selective weathering of more lithified trace fossils and burrows in the form of nodules and tubes with a diameter of 1.5 to $3 \mathrm{~cm}$ that occur $0-3 \mathrm{~m}$ and 11-20 $\mathrm{m}$ above the base of the composite profile (Fig. 8F). An uneven undulose contact of layers can be seen (15.2 to $19 \mathrm{~m}$ ) in cases where an overlaying layer is pressed into an underlying one. A wedge-shaped bed contact was observed between 16.2 and $18.6 \mathrm{~m}$, where a $160 \mathrm{~cm}$ deep and $40 \mathrm{~cm}$ wide wedge with a NE-SW axis (Figs. 3D and 8B), and another with a NW-SE orientation (Fig. 3E) was observed. In the uppermost part of the sequence (20.1 m; Fig. $8 \mathrm{C}$ ), a $1 \mathrm{~cm}$ rust-coloured sandy layer occurs.

The middle sequence (20.1 to $21.6 \mathrm{~m}$ above the base of the composite profile) is weakly lithified and formed by barren variegated siliciclastic sand and pebble gravel with rusty 
A

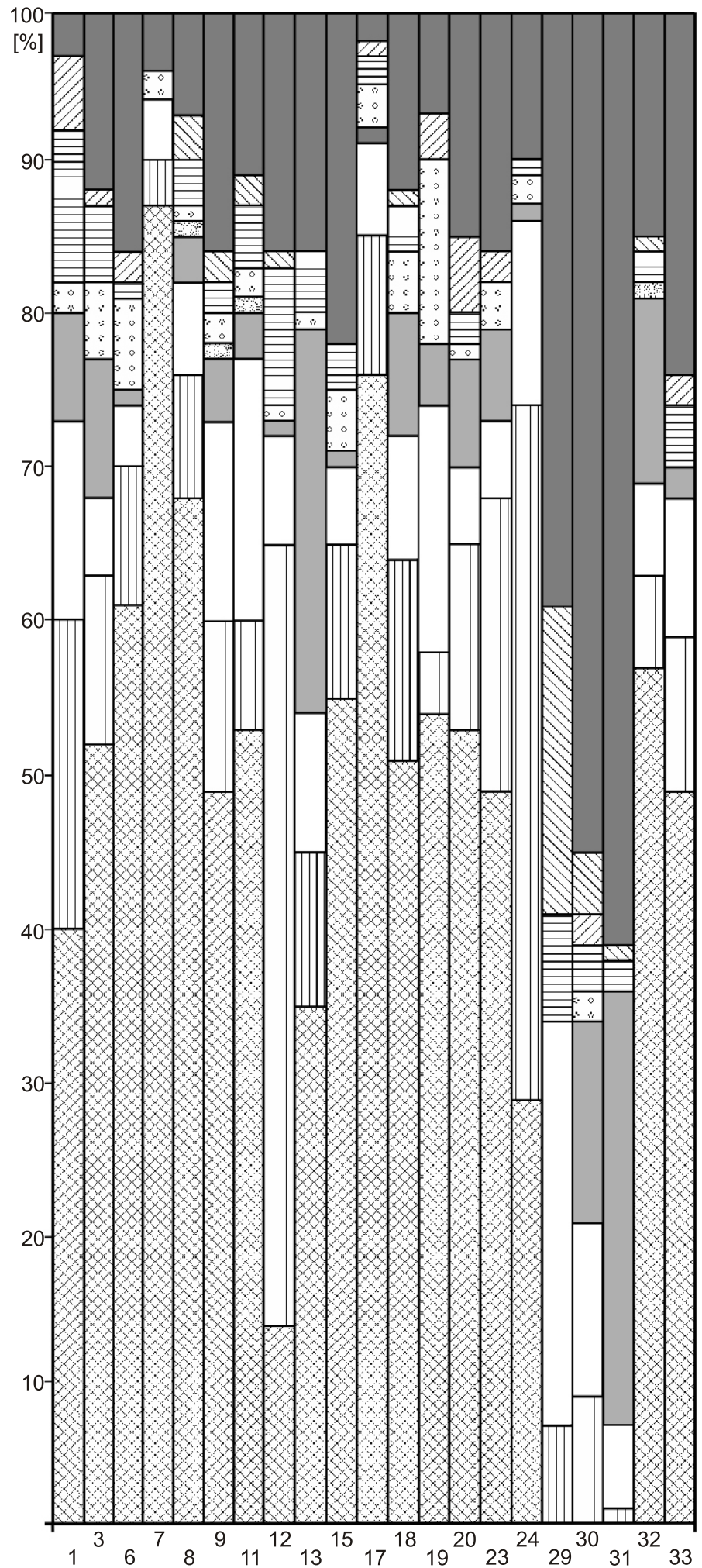

B
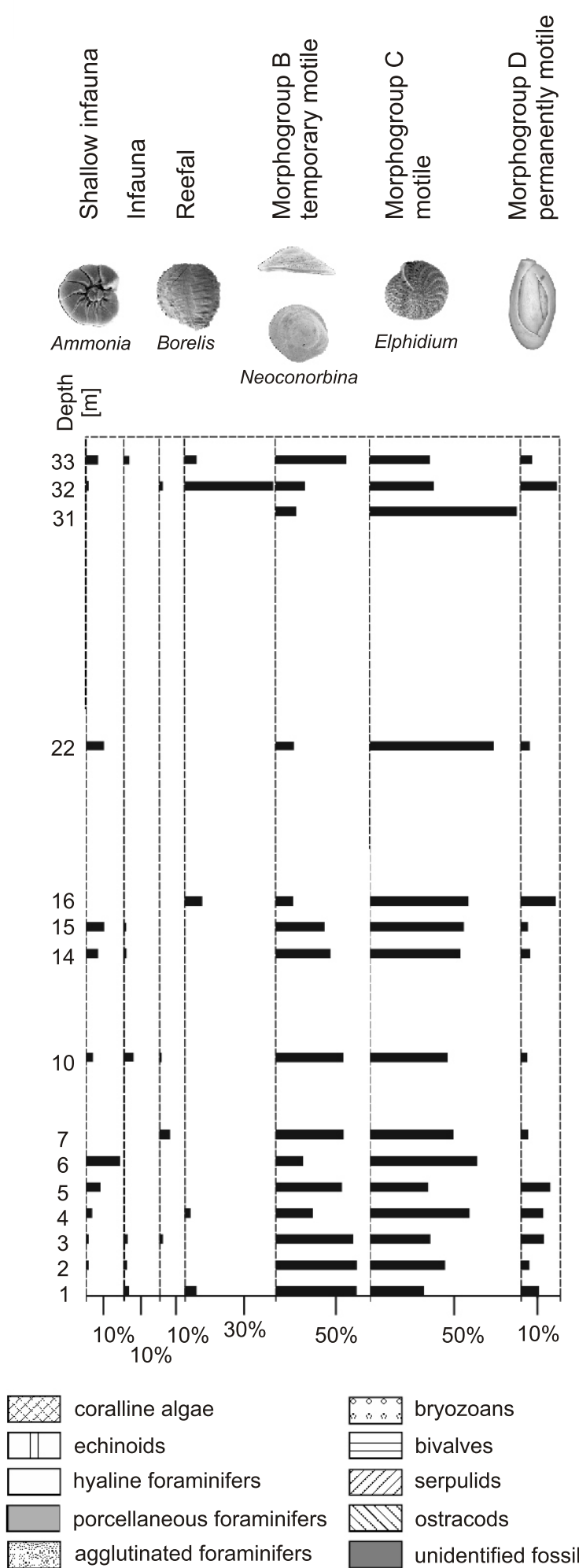

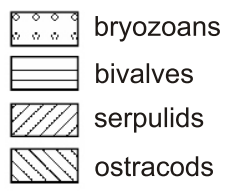
unidentified fossils

Fig. 4A - fossil distribution within the section studied; B - foraminiferal groups distribution within the section studied (groups determined after Langer, 1993) 


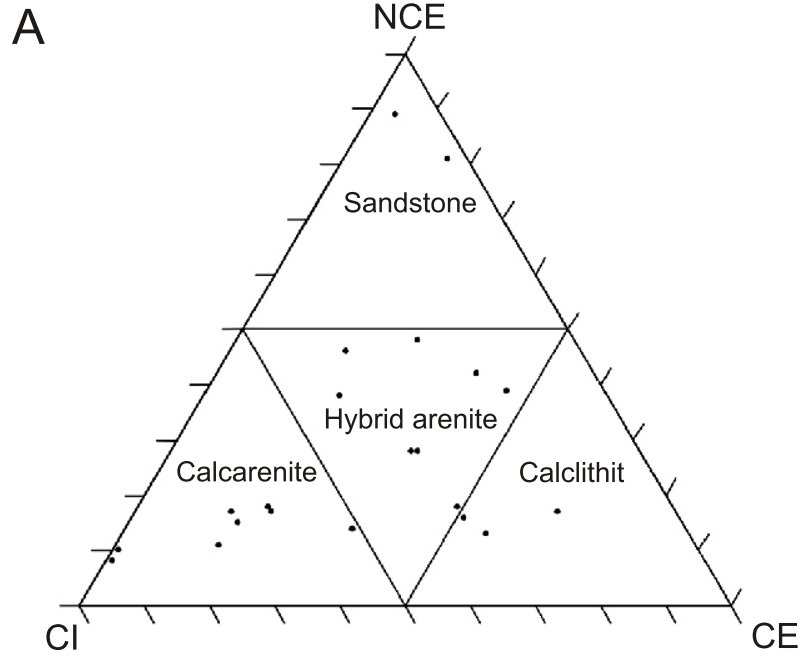

B

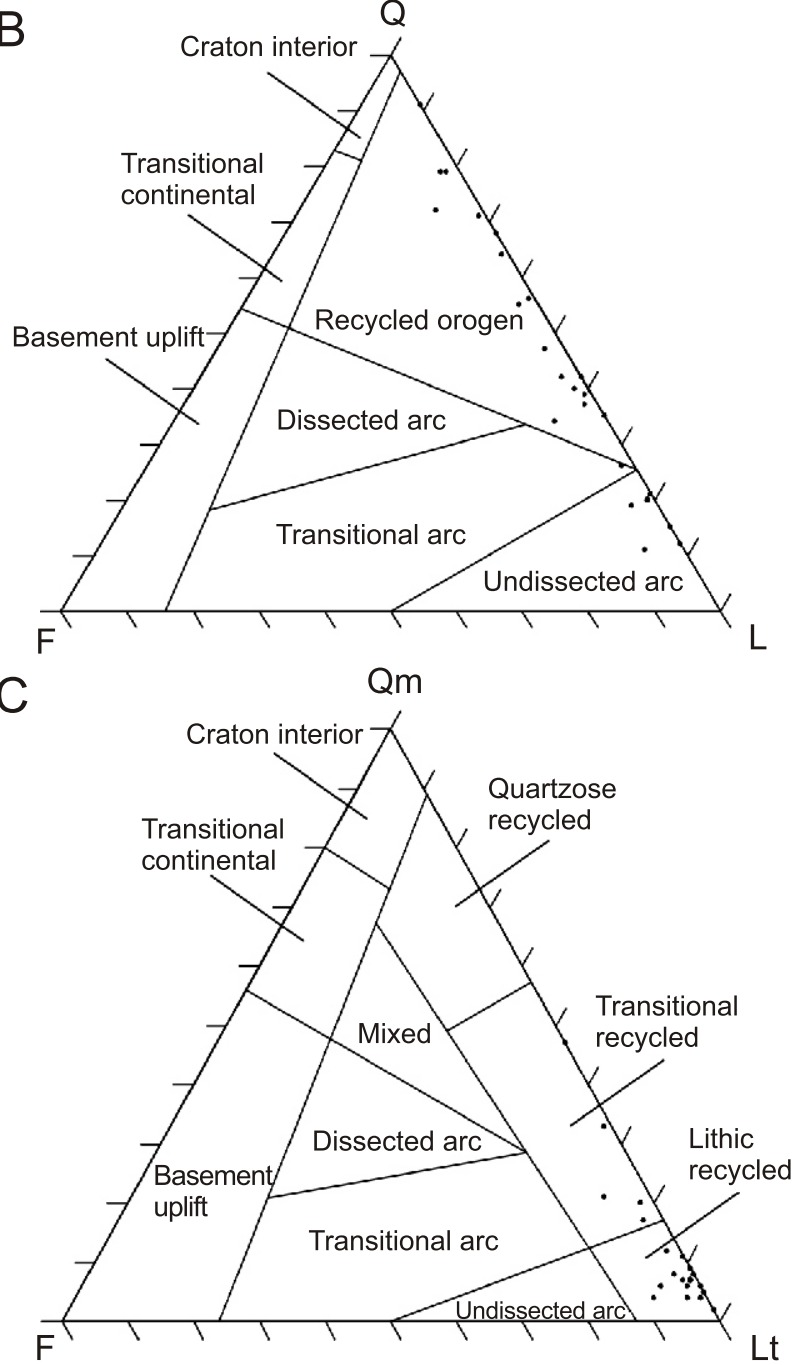

Fig. 5. Sandstone classification ternary diagrams

A - main types of arenite, according Zuffa (1980): NCE - siliciclastic material of non-carbonate extrabasinal origin, $\mathrm{CE}$ - older carbonates of carbonate extrabasinal origin, $\mathrm{Cl}$ - fossils and intraclasts of carbonate intrabasinal origin; B - QFL ternary provenance discrimination diagram of sandstones, according to Dickinson (1983): Q quartz, F - feldspar, L - lithic fragments; C - QmFLt ternary provenance discrimination diagram of sandstones, according to Dickinson (1983): Qm - quartz monocrystalline, F - feldspar, Lt lithic and composite quartz streaks. The sequence starts with a $10 \mathrm{~cm}$ thick layer of rusty coarse sand to clay. The following $40 \mathrm{~cm}$ is formed of beige-grey, mostly fine sand with coarser layers possessing rusty streaks. In this sequence, irregular, locally wavy or discontinuous white laminae of micritic calcite up to $1 \mathrm{~cm}$ thick and locally rhizoliths occur. Above that, a 100 to $130 \mathrm{~cm}$ thick set of irregular and discontinuous sand and gravel beds was observed (Fig. 8D). The bottom layer of this set is composed of gravel with a grain size of $1-4 \mathrm{~cm}$. Gravel to sandy bodies show ambiguous channel to planar cross-bedding structures. The bottom part of each body is characterised by a layer of gravel and becomes finer towards the top. The deposit is marked by stripes of precipitated iron oxyhydroxides.

The upper sequence (21.6-27 $\mathrm{m}$ above the base of the composite profile) is formed of light grey sand (from 21.6 to $21.9 \mathrm{~m}$ ) with scattered granules $(2-3 \mathrm{~mm})$, calcrete intraclasts, burrows, and lacking macrofossils is irregularly loaded into the sand and gravel of the middle sequence (Fig. 8D, E). A layer of conglomerate to coarse grain sandstone (21.9-27 m above the base of the composite profile) is situated above the light grey sand. The basal part of this conglomerate $(40 \mathrm{~cm})$ is clast-supported and contains the coarsest material in the entire quarry, mostly from 2 to $7 \mathrm{~cm}$ across (up to $12 \mathrm{~cm}$ ). In the layer above, the size of the grains reaches from 0.5 to $2 \mathrm{~cm}$ (rarely up to $10 \mathrm{~cm}$ ). Conglomerate layers alternate with limestones rich in siliciclastic material. The top 3 metres of the profile, close to the Quaternary surface, are strongly weathered. In the uppermost part, a friable calcrete with patches of the original rock is present.

\section{THIN SECTION ANALYSIS: PETROGRAPHY AND MICROFACIES}

Throughout the entire log, the siliciclastic material is represented by monocrystalline and polycrystalline quartz, often with undulose extinction, with subordinate metamorphic clasts of two types - yellow to rusty fine-grained rock with a predominance of weathered phyllosilicates with goethite, and the rock with quartz, sericite and rarely with biotite. Individual mineral grains are represented by separate goethite spots (weathered biotite), flakes of muscovite and biotite, weathered feldspar and feldspar-quartz aggregates, potassium feldspar, plagioclase and myrmekite. Carbonate rocks are formed of sparite, rarely of microsparite with occasional foliation, micrite and cloudy sparite locally with quartz grains. In terms of carbonate classification (Dunham, 1962; Embry and Klovan, 1971), the deposits studied are mostly packstones, fewer grainstones, rudstones and boundstones. They belong to the biomicrite to biosparite categories (Folk, 1962).

Rusty sediment (20.1 to $20.2 \mathrm{~m}$ above the base of the composite profile) is coloured by Fe-hydroxides of globular form $(5-20 \mu \mathrm{m})$. In the overlying sand (20.2 to $20.6 \mathrm{~m}$ above the base of the composite profile), white laminae containing micrite to microsparite with siliciclastic grains, pellets and oval holes, in places coated by a thin sparite film (Fig. 9B). Microcodium structures and larger grains coated by clay (skelsepic fabric) are also documented in this interval.

The dominant fossils (Figs. 9-11) observed in thin sections are coralline algae $(46 \%)$, sea urchins $(13 \%)$, porcellaneous foraminifera $(7 \%)$, hyaline foraminifera $(7 \%)$, bryozoans $(4 \%)$, bivalves $(2 \%)$, polychaetes $(2 \%)$, ostracods $(1 \%)$ and agglutinated foraminifera $(0.2 \%)$.

Algal abundance ranges from $<1 \%$ in sample 30 up to $87 \%$ in sample 7 (algal floatstone to boundstone; Fig. 10). Samples 25-29 do not contain any algal fragments. Fragmented echinoid shells and spines are present in the entire profile with abundance from 1 to $50 \%$ (Fig. 9G-J). In two samples $(12,24)$, echinoids prevail over algae, while samples $25-28$ contain no 


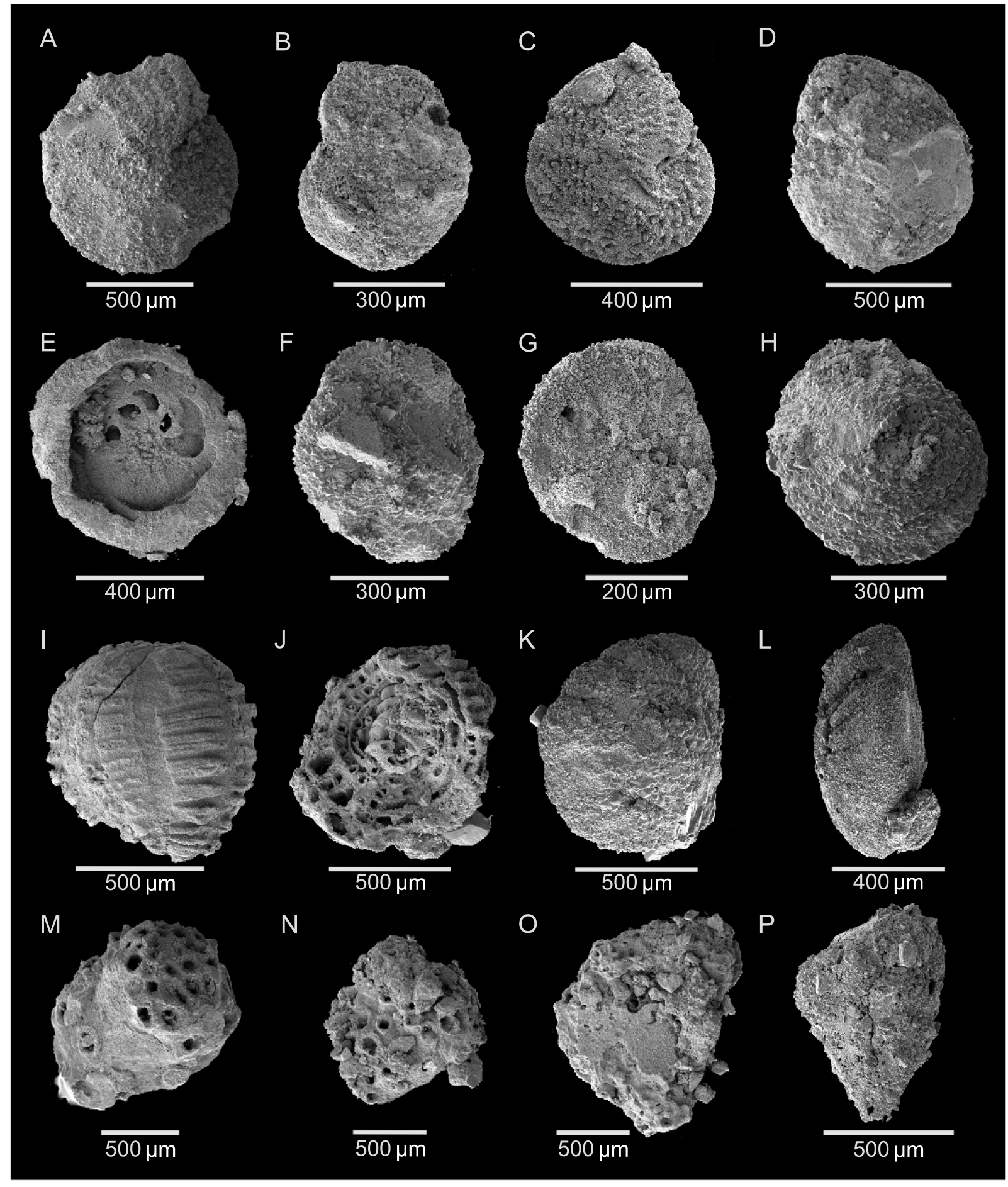

Fig. 6. Foraminifera

A - Elphidium macellum (Fichtel and Moll, 1798), sample 3; B - E. fichtellianum (d'Orbigny, 1846), sample 14; C - E. crispum (Linnaeus, 1758), sample 32; D - E. sp. de Montfort, 1808, sample 32; E - Neoconorbina terquemi (Rzehak, 1888), sample 15; F - N. terquemi (Rzehak, 1888), sample 3; G - N. terquemi (Rzehak, 1888), sample 4; H - N. terquemi (Rzehak, 1888), sample 3; I - Borelis melo (Fichtel and Moll, 1798), sample 4; J - B. melo (Fichtel and Moll, 1798), sample 4; K - Ammonia parkinsoniana (d'Orbigny, 1839), sample 4; L - A. parkinsoniana (d'Orbigny, 1839), sample 3; $\mathbf{M}$ - Miniacina miniacea (Pallas, 1766), sample 14; $\mathbf{N}-\mathbf{M}$. miniacea (Pallas, 1766), sample 15: O - Sinzowella sp., sample 14; P - Textularia sp., sample 15 

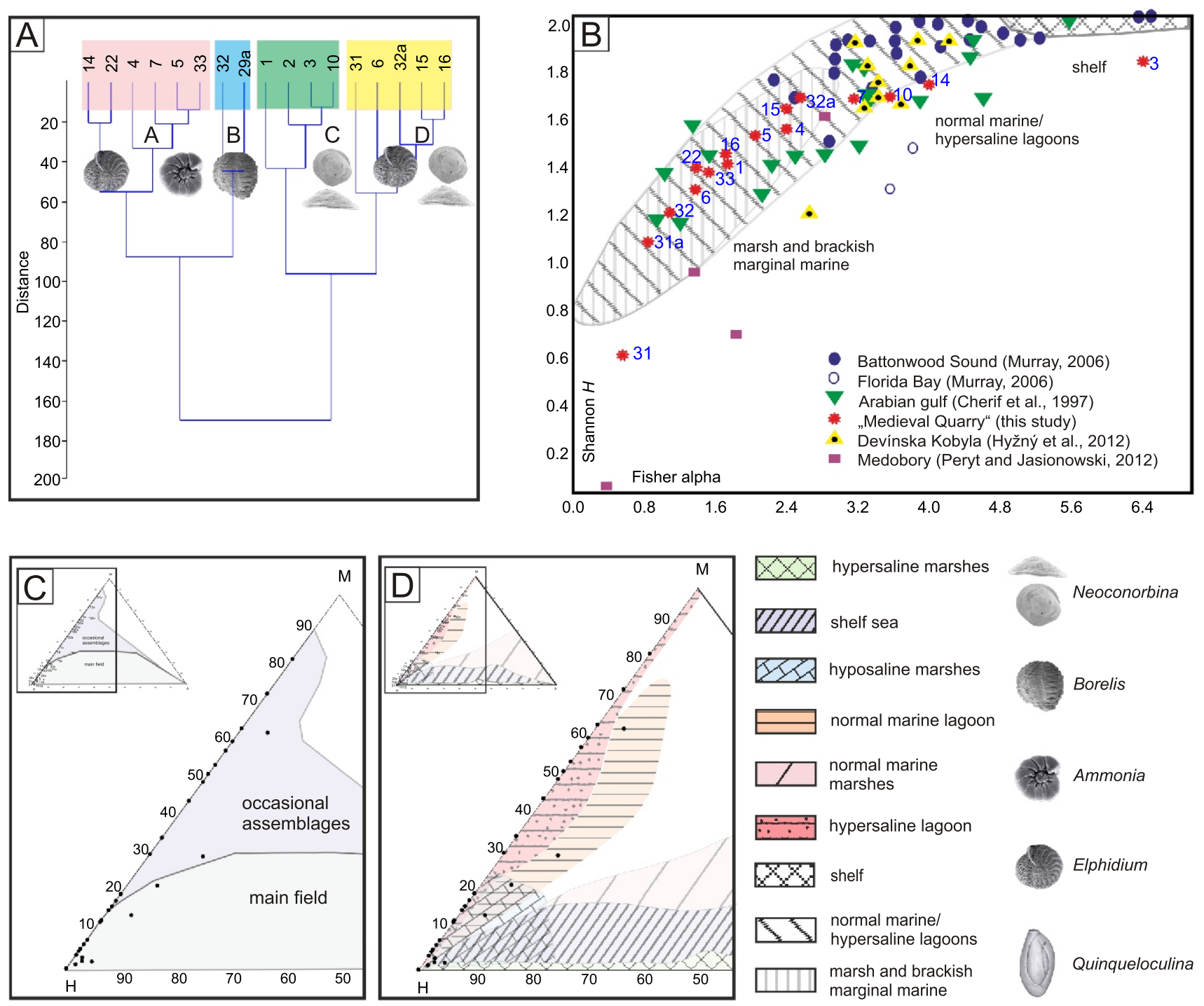

Fig. 7. Statistical analysis of benthic foraminiferal assemblages

A - cluster diagram, Wards method, groups at distance level 60; B - relationship between diversities Shannon $\mathrm{H}$ and Fisher alpha, Murray's (2006) interpretation was applied; C, D - ternary diagrams of wall structure ratio (hyaline, porcellaneous and agglutinated), Murray's $(1973,2006)$ interpretation was applied

echinoids. The abundance of echinoid bioclasts correlates positively with the predominance of hyaline over porcellaneous foraminifera. The spines (sensu Kroh and Nebelsick, 2010) are mostly from the cidaroid group, with fewer from the spatangoid and diadematoid groups. Samples 8, 9, 15 and 17 also contain rare cassiduloid, echinacean and echinoneoid spines.

The thin sections contain many hyaline foraminiferal tests of the genera Elphidium, Miniacina and Neoconorbina as well as porcellaneous forms of Quinqueloculina and Borelis (Fig. 9A, C-E). Within agglutinated forms, only textulariids were rarely observed. Bryozoans are represented mainly by cheilostomes. Oyster fragments were also observed. Among the ostracods, smooth valves (both thin and thick) prevail, while sculptured ostracods are found only in the uppermost samples $(29,30)$. Different types of worm tubes with laminated black or brown walls were observed (Fig. 9H). Micrite coatings and nodules as well as green algae occur in sample 31.

\section{THIN SECTION ANALYSIS: CORALLINE ALGAE}

Most algal thalli do not possess well-preserved diagnostic features, making the identification of genera or even subfamilies difficult. All identified species belong to the order Corallinales. The order Sporolithales is not present. The most abundant genus in algal assemblages is Mesophyllum, less frequent are Lithothamnion, Lithophyllum and Spongites, while thin encrustations of Titanoderma and Hydrolithon are rare. Melobesioideae coralline algae are a dominant subfamily, while the subfamilies Neogoniolithoideae, Lithophylloideae and Hydrolithoideae are subordinate.

The coralline algae observed form simple unattached protuberances with single dichotomous branching without nuclei (sample 7, 8, 32). Although rhodoliths with a higher protuberance degree (branch density sensu Bosence, 1983) were not directly observed, the anatomy of neighbouring protuberances 

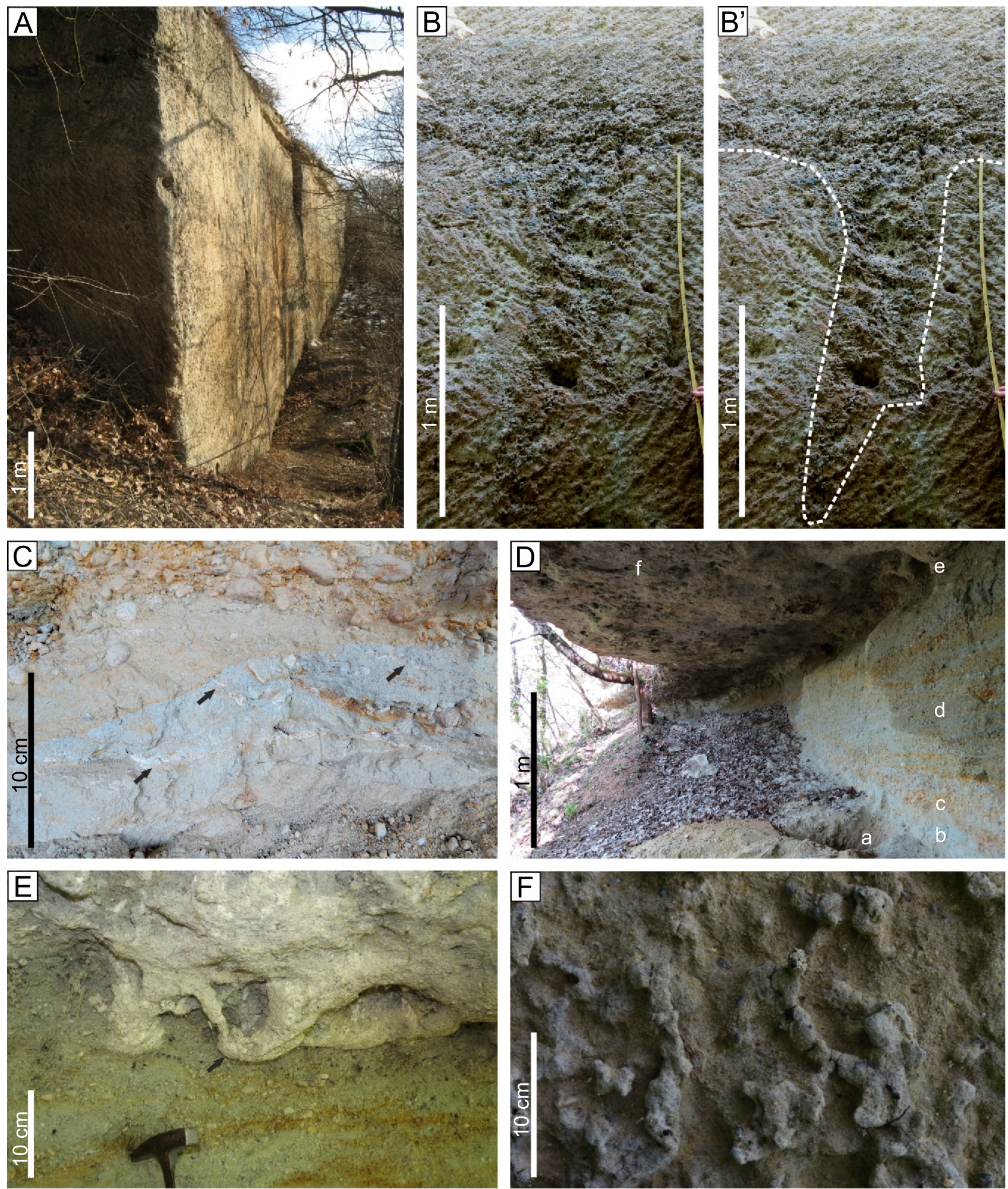

Fig. 8. Sedimentary structures in the "Medieval Quarry"

A - quarry face; B - clastic dike wedge of coarser sediment incised into the underlying finer sediment; B' - interpreted; C - terrestrial sediment with calcrete horizons (arrowed) and residual fluvial gravels; D - regolith with calcrete (b), fluvial gravel-sand sediment (d) with residual gravel (c) between marine sandstone (a) and sand (e) to conglomerate (f); E - grey marine sand loaded into the fluvial sediment, arrow points to a burrow; $\mathbf{F}$ - crustacean burrows in coarse sandstone 

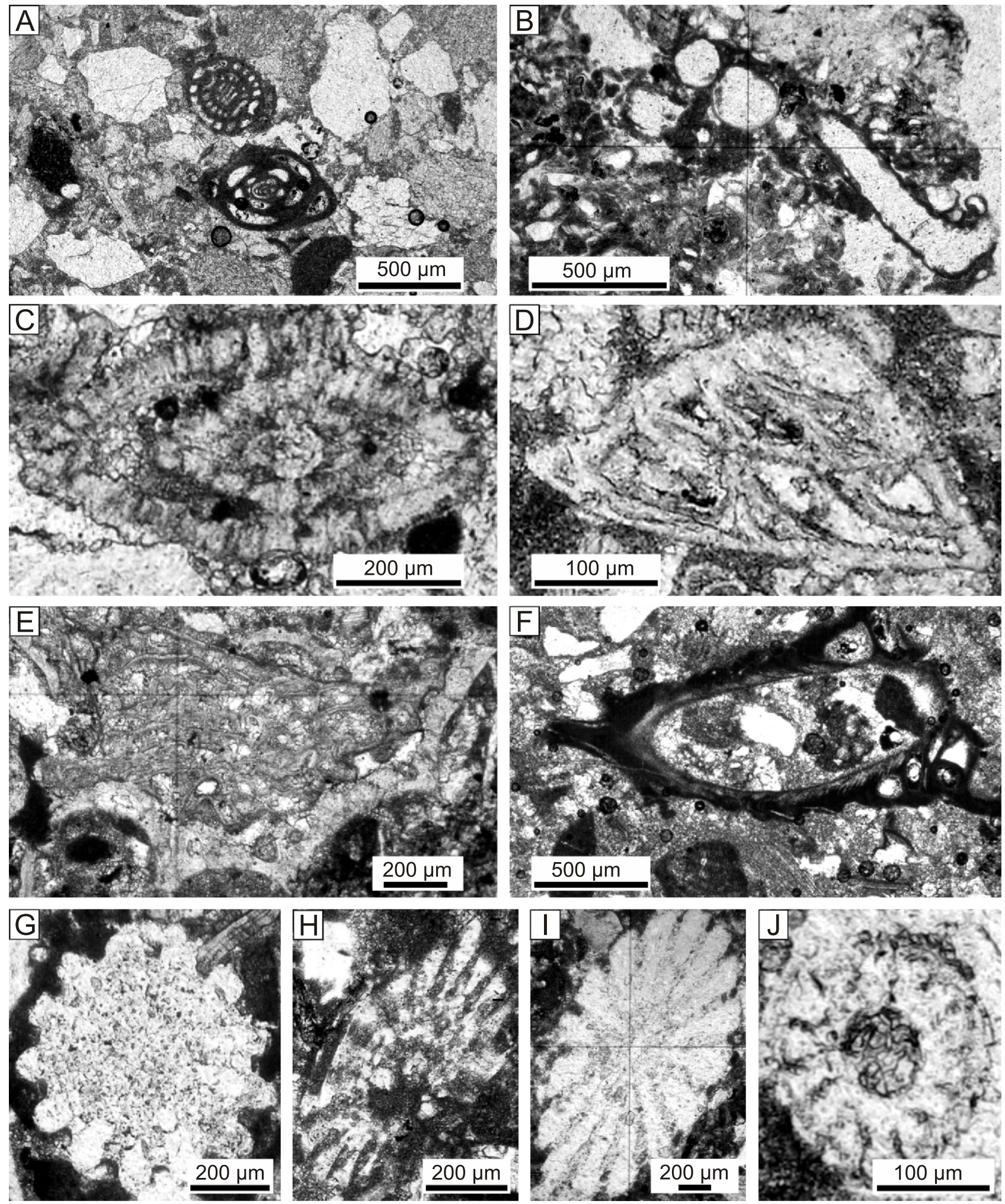

Fig. 9. Thin sections - microfossils

A - hybrid sandstone with fossils (e.g., Borelis sp., Quinqueloculina sp.), siliciclastic and carbonate rock clasts, sample 13; B - calcrete with rhizoliths, sample 26; C - Elphidium sp., sample 1; D - Neoconorbina sp., sample 7; E - Miniacina sp., sample 8; F - serpulid tube, sample 20; G - cidaroid spine, sample 8; H - diadematoid spine, sample 8; I - echinacean spine, sample 8; J - spatangoid spine, sample 17 

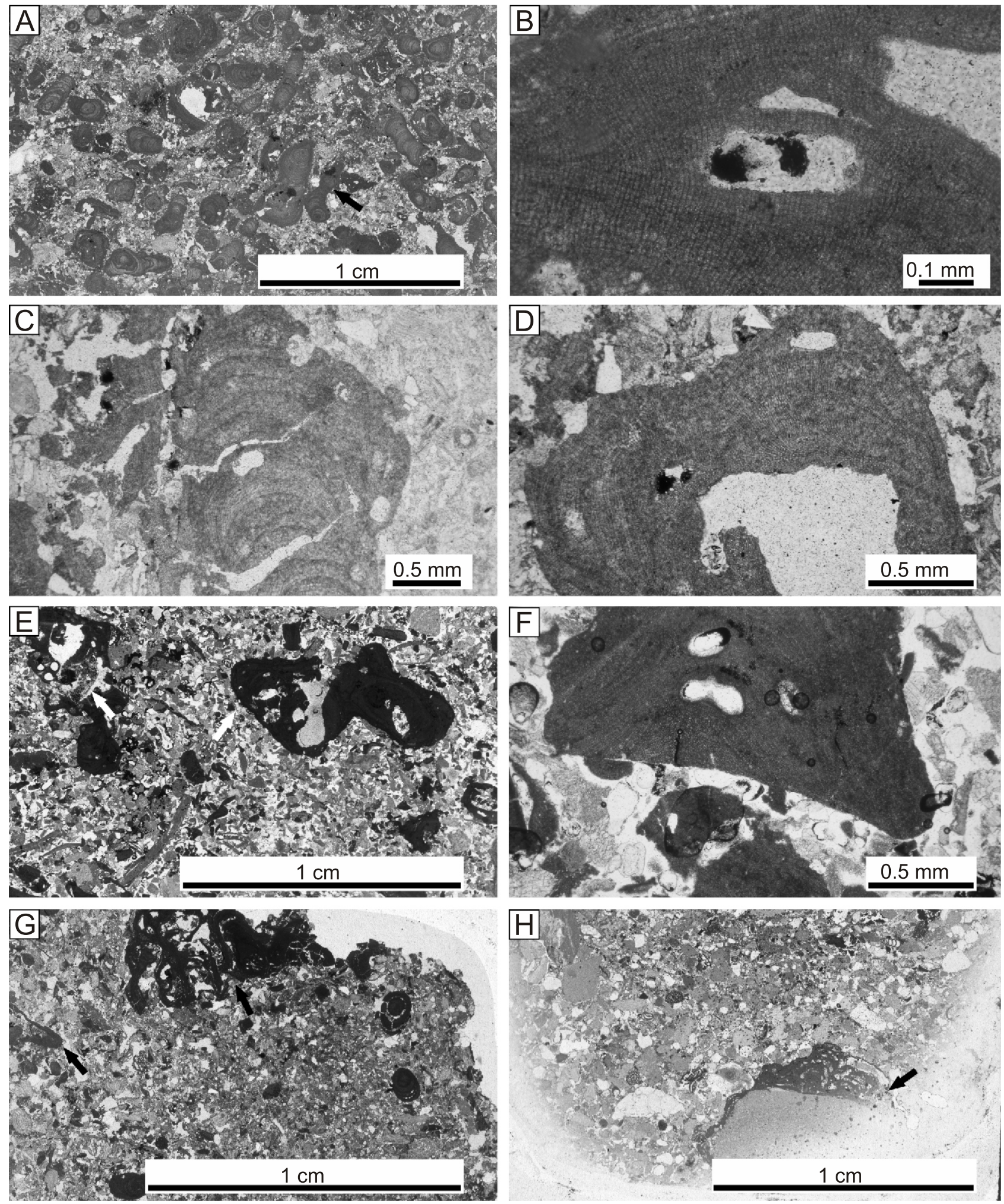

Fig. 10. Thin sections - algae

A - accumulation of simple branched protuberances (arrowed) - maërl, note local higher accumulation of muddy matrix trapped inside the construction, sample 7; B - coralline algae of the genus Lithothamnion Heydrich, sample 9; C - coralline algae of the genus Mesophyllum Lemoine, sample 7; D - coralline algae of the genus Lithophyllum Philippi, sample 7; E - subrounded fragments of compact monospecific rhodoliths - pralines (arrow), note the nuclei in the top-left fragment (arrowed), muddy content is less common, sample 19; $\mathbf{F}$ - coralline algae of the genus Spongites Kützing, sample 19; G - fragment of large rhodolith with loose structure and primary voids - box-work type (arrowed), hooked structure is in left margin of the figure (arrowed), sample 9; $\mathbf{H}$ - pebble coated by a coralline algae and serpulids (arrowed), protuberance at the top suggests direction of growth, sample 13 

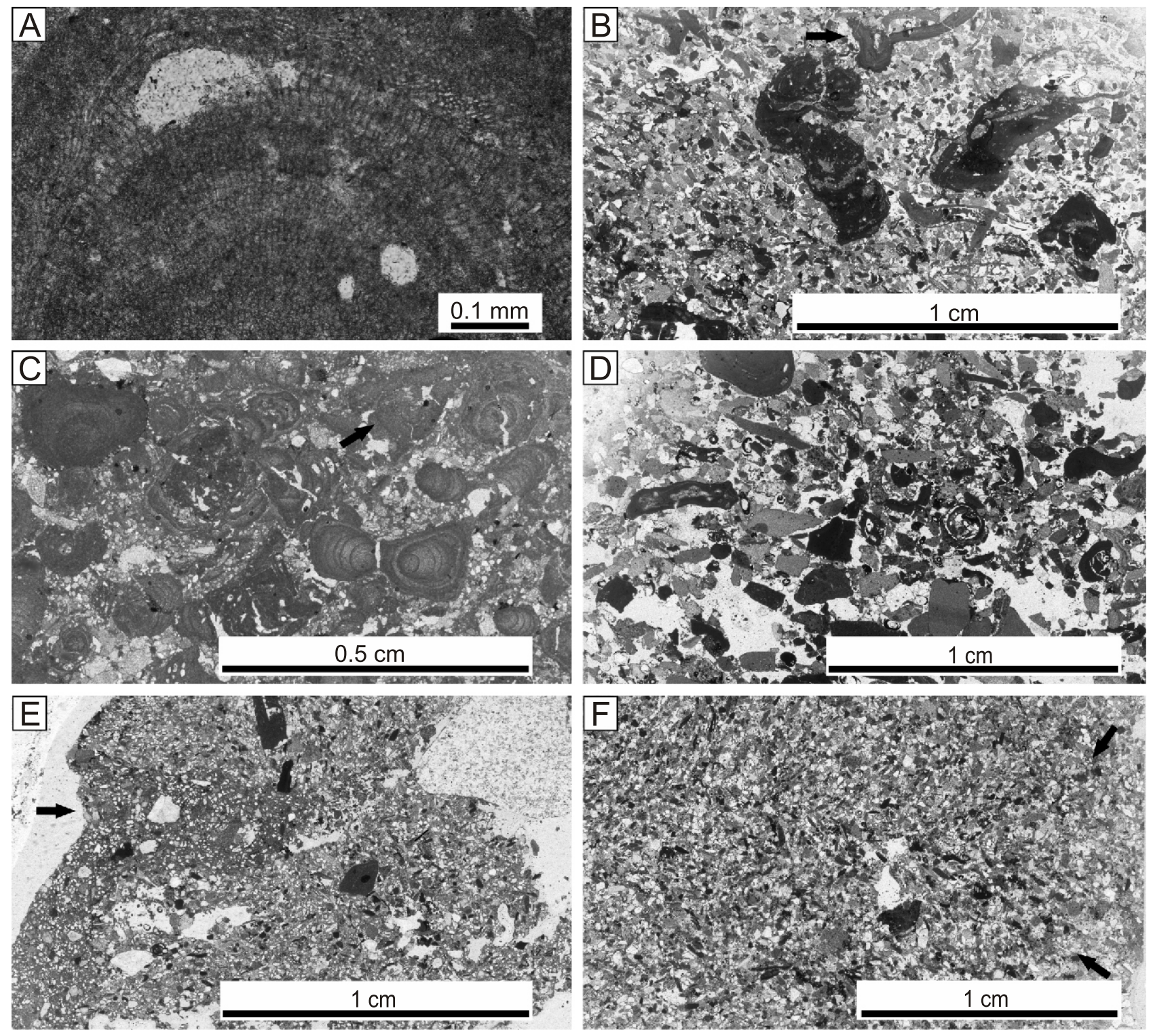

Fig. 11. Thin sections - algae

A - coralline algae Titanoderma pustulatum (Lamouroux) Nägeli, sample 7; B - fragments of subrounded - subangular coralline algae, note hooked structure at top of the figure (arrowed), sample 19; C - maërl, arrow points to the hooked structure, sample 7; D - sample with debris of coralline algae, higher content of coarse-grained matrix and absence of mud is evident, sample 17; E - burrow (arrowed), sample 3; F cross-bedding, directions of bedding are indicated by arrows, sample 1

does not completely exclude them. The protuberances observed are lumpy to fruticose and are formed by Mesophyllum (Fig. 10C), Lithothamnion, and Lithophyllum (Fig. 10D). Larger fragments of compact rhodoliths (praline type sensu Basso, 1998) with warty protuberances are also present (Fig. 10E; sample 19). The praline rhodoliths have a compact internal structure and distinct nuclei which separate them from non-nucleated maërl, mainly composed of unattached branches (Bosence, 1976; Basso, 1998). The monospecific rhodoliths are formed of Mesophyllum, Lithophyllum or Spongites (Fig. 10C, F). A fragment of a multi-specific rhodolith with loose growth of thalli and common primary constructional voids ("boxwork" sensu Bosence, 1983) was also observed (Fig 10G; sample 9). This fragment consists of Lithothamnion (Fig. 10B), uncertain Melobesioideae, and encrustations of monostromatic thalli with fused cells most likely belonging to the Mastophoroideae or Hydrolithoideae. Encrusting growth forms are non-protuberant. Pebbles coated by Lithothamnion and uncertain thalli (Fig. 10H), and bryozoan colonies encrusted by Mesophyllum were also identified. Loosely hooked structures and algal flakes (sensu Sola et al., 2013) were observed in the thin sections (Figs. 10G and 11C; samples 6, 7, 9, 17).

Small, angular to subrounded clasts of all these algal growth forms are the most abundant algal element in all the thin sections.

FORAMINIFERS

Forty-eight foraminiferal taxa were identified in the 22 samples studied (18 positive). The preservation level allowed the determination of 29 species, while 19 taxa stay in open nomenclature (Appendix $\left.1^{*}\right)$. The major determination obstacle was a strong secondary calcification of tests which directly covered the original ornamentation (Fig. 6). From a biostratigraphical point of view, Sarmatian index taxa were identified in samples 
32, 32a, 16, 3, 2 (Nodobaculariella sulcata), 32, 32a, 22 (Elphidium josephinum), 32, 10 (E. cf. reginum) and in samples 10, 14, 7, 4, 3, 2 (E. aff. josephinum).

In all samples studied, specimens of Elphidium are the most abundant (Fig. 6A-D), which exceed 50\% (samples 29a, 22, $16,15,14,10,9,6,4$ ), and up to $88.2 \%$ (sample 31 ) in the assemblages. The dominant species is Elphidium crispum which comprises around $52 \%$ (samples 15,16 ) and up to $82.35 \%$ (sample 31; Appendix 1). Neoconorbina terquemi is the second most dominant species and reaches from $0 \%$ (samples 33 and 32 ) to $38 \%$ (sample 3 ). In the lower part of the profile (samples 1-14), a dominance of Neoconorbina terquemi is very consistent $(25-38 \%)$ and up to $8 \%$ in sample 8 . A decreasing trend in the proportion of Neoconorbina terquemi of up to $10-12 \%$ (samples 15-32) and up to $41.9 \%$ (sample 33), was observed. The content of the dominant Elphidium crispum fluctuated significantly. The ecologically important species Ammonia parkinsoniana forms from $1 \%$ (3) up to $24 \%$ (sample $29 a$ ). Reussella spinulosa reaches almost $10 \%$ in sample 5 (Appendix 1).

The porcellaneous foraminifers generally do not exceed $15 \%$. Small porcellaneous species are very badly preserved in all samples studied; therefore, they are determined at generic level only. A positive correlation between the high abundance of Borelis melo (Fig. 6l, J) and small porcellaneous species was observed (samples 16, 32, 32a).

The average of simple species diversity (SSD) of the studied assemblages is low (SSD 8.9) due to the prevalence of the low-diversity samples (SSD 4-18). The Shannon $\mathrm{H}$ and Fisher $\alpha$ diversity indices also reach very low values $(H=0.5$ to $2 ; \mathrm{F} \alpha=$ 0.6-6.0; Fig. 7B). The wall structure ternary diagram (Fig. 7C D) reveals a very low portion of agglutinated foraminifers in all samples studied (both in residua and in thin sections).

Depth estimation (sensu Hohenegger, 2005; Hohenegger, pers. comm. 2009) shows a very shallow depth with a minimum of $7.5 \mathrm{~m}$ (sample 16) and a maximum of $28 \mathrm{~m}$ (sample 5). Due to the presence of extremely eurybathic taxa, a wide error interval in several samples was obtained (Appendix 2). Cluster analysis based on the species absolute abundances shows four groups of samples at a similarity level of 60 (Fig. 7A).

Group A (Fig. 7A and Table 1) comprises six samples (14, $22,4,7,5,33)$. The average content of Ammonia parkinsoniana $(5.6 \%)$ and Elphidium sp. $(42.5 \%)$ is the highest within all four groups, while E. crispum is absent. The proportion of Quinqueloculina sp. is about 2.7 from $<1 \%$.

Group B (Fig. 7A and Table 1) comprises two samples (32, 29a). The proportion of Elphidium $\mathrm{sp}$. is $31.4 \%$, while Neoconorbina terquemi (Fig. 6F-H) is absent.

Group C (Fig. 7A and Table 1) comprises four samples (1, $2,3,10)$. The samples show the highest portion of $N$. terquemi $(39.8 \%)$ within all groups, and contain A. tepida $(1.1 \%)$ which is absent from the other groups. The proportion of the smaller porcellaneous forms of Quinqueloculina and Triloculina genera is $\sim 4.3 \%$.

Table 1

Cluster analysis four main sample groups

\begin{tabular}{|l|c|c|c|c|}
\hline & $\begin{array}{c}\text { Simple species } \\
\text { diversity }\end{array}$ & Dominance & $\begin{array}{c}\text { Shannon } \\
H\end{array}$ & Fisher $\alpha$ \\
\hline Group A & 6.8 & 0.32 & 0.67 & 2.39 \\
\hline Group B & 4.5 & 0.30 & 0.70 & 0.97 \\
\hline Group C & 14.0 & 0.26 & 0.73 & 4.60 \\
\hline Group D & 6.8 & 0.38 & 0.61 & 1.70 \\
\hline
\end{tabular}

Group D (Fig. 7A and Table 1) comprises 5 samples (31, 6, $32 a, 15,16)$. The average proportion of E. crispum is $53.3 \%$ and $N$. terquemi is $14 \%$ in this group.

\section{INTERPRETATION AND DISCUSSION}

\section{FOSSIL ASSEMBLAGES}

The age of the deposits based on benthic foraminiferal assemblages indicates a Badenian to Sarmatian age (Fig. 2). The common occurrence of Badenian (Globigerina sp.) and Sarmatian (Elphidium josephinum, E. reginum) species points to the reworking of Badenian sediments into younger ones (samples 22, 32). The occurrence of Titanoderma pustulatum indicates marine connection with the Eastern Paratethys during the Early Serravallian (Bassi et al., 2009).

Coralline algal growth forms were used as a tool for palaeoenvironmental interpretation. In this study, the growth forms determined are linked to those established by Pérès and Picard (1964) and discussed by Basso (1998) and Pergent et al. (2007) from the Mediterranean sublittoral environments and their sedimentary facies. The praline type of rhodoliths represent the fossil equivalents of infralittoral biocenoses of "coarse sands and fine gravels mixed by waves" and "coarse sand and fine gravels under bottom currents (SGCF)" and the circalittoral biocenose of "coastal detritic" (DC). The presence of praline rhodoliths in sediment thus points to a sandy bottom influenced by waves or bottom currents (Pergent et al., 2007) and to grazers' bioturbating activity (Birkett et al., 1998). Sediment with unattached protuberances called maërl (Fig. 10A) is typical for a sandy seabed variably influenced by bottom currents (SGCF and DC; Pergent et al., 2007). Current energy should be high enough to prevent thalli from accumulating mud coatings and low enough to prevent mechanical destruction by abrasion (Bosence, 1976; Basso and Tomaselli, 1994).

Benthic foraminiferal assemblages document sedimentation in the shallow-water of a marginal sea. Low assemblage diversities (Fig. 7B) allow us to speculate about brackish-normal marsh or normal marine (sample 9, 8, 32) or hyperhaline (sample 13, 31) lagoon environments (Fig. 7B-D) similar to those of the Arabian Gulf (Cherif et al., 1997). According to the ternary diagram (Murray, 2006), shelf environments cn be divided into the typical and occasional (Fig. 7C, D). Interpretation of the environment could be biased by the influence of taphonomic processes. Synsedimentary dissolution of the porcellaneous forms (Westphal, 1998), or disintegration of agglutinated tests (Berkeley et al., 2009) restrict environmental interpretations.

The lowermost part of the profile studied ( $0-2 \mathrm{~m}$ above the base of the composite profile), similar to the upper part (17-19.5 $\mathrm{m}$ and $23 \mathrm{~m}$ above the base of the composite profile), document a sheltered lagoon-to-shelf environment of normal or high salinity. This is also supported by the prevalence of porcellaneous forms with a dominance of Borelis melo. The middle part of the profile displays a more open environment of fluctuating salinity.

The distribution of foraminiferal assemblages was influenced primarily by food availability, rather than by substrate. The prevalence of epiphytic foraminifers (Fig. 4B) documents a seabed colonized by algae and seagrasses (e.g., Langer, 1993; Murray, 2006). The dominant epiphytic taxa belong to morphogroups B and C (sensu Langer, 1993), such as Neoconorbina of the morphogroup B or keeled elphidiids of morphogroup C. In some samples $(5,6)$, a high number of arborescent foraminifera such as Miniacina miniacea of mor- 
phogroup A was observed. M. miniacea is typically attached to rhizomes in shaded microhabitats of Posidonia (Gaglianone et al., 2015) or onto the lower side of the calcareous red alga Lithophyllum (as Pseudolithophyllum in Langer, 1993).

Due to the higher portion of typical reefal foraminifers (Borelis melo, Peneroplis sp.; e.g., Thissen and Langer, 2014) the proximity of a patch reef (see Baráth, 1992), or maërl can be assumed in the lowermost (sample 1,4), middle (sample 16) and uppermost parts (samples 32, 32a, 33).

A more agitated rocky or coarse-grained sea bed (Kroh and Harzhauser, 1999; Kroh and Nebelsick, 2010) can be inferred from the dominance of regular sea urchins over irregular, because spatangoids (between 7-17 $\mathrm{m}$ above the base of the composite profile) prefer a calmer sandy bottom of shallow sublittoral, even lower infralittoral type (Kroh and Harzhauser, 1999; Kroh and Nebelsick, 2010). Therefore, we can assume post-mortem mixing of the echinoid remnants of the different environments. A mature ecosystem with a water depth of 50-100 $\mathrm{m}$ was inferred from the dominant presence of cheilostomate bryozoans (K. Zágoršek, pers. comm., 2016).

Most of the profile corresponds to the rhodechfor assemblage, as described by Hayton et al. (1995) from the Miocene of New Zealand. According to Hayton et al. (1995) and Flügel (2010), this is formed by the prevalence of coralline algae $(<80 \%)$, fewer sea urchins, benthic foraminifers and bryozoans, apart from the terrigenous content. Rarely, echinoids exceed coralline algae. On the basis of the benthic foraminifers, water depth was estimated at between 20 to $30 \mathrm{~m}$. We recognise two kinds of rhodechfor. The first forms a rim around the algal bioherm (rhodalgal) and the second, with a high amount of clastic material, forms a rim along the coast.

In the lower part of the profile, a different fossil association with a higher portion of red algae $(>80 \%)$ corresponds to a rhodalgal assemblage (sensu Hayton et al., 1995). A similar setting, described by Hayton et al. (1995) from New Zealand, shows a link between the light demands of the rhodalgal bioherm top and rhodechfor dwellers of the deeper rim.

Red algal reefs were common structures in the Middle Miocene of the Paratethys Sea (Pisera, 1996; Górka et al., 2012; Peryt and Jasionowski, 2012). While rhodalgal assemblages were often identified in Miocene deposits (Hayton et al., 1995), rhodechfor has rarely been described (Pomoni-Papaioannou et al., 2002; Knörich and Mutti, 2003). A rhodechfor assemblage forms a significant part of the Badenian porous limestones at St. Margarethen in Austria (D. Pivko, personal observation).

\section{CLIMATE}

Overall a warm-moderate climate can be inferred from the fossil rhodechfor and rhodalgal assemblage evaluations. Carrannante et al. (1988) defined rhodalgal as a transitional lithofacies between tropical chlorozoan and cool-temperate molechfor. Rhodalgal facies of the Mediterranean Sea are considered as recent analogues of Miocene limestones (Carannante et al., 1988; Basso, 1998, Studencki, 1999). Rhodalgal lithofacies of the recent Mediterranean Sea are extensive accumulations of rhodoliths or attached hard substrate bioconstructions formed by coralline algae (Basso, 1998; Basso et al., 2015). According to a recent classification, samples identified with algal protuberances are correlated with maërl, defined as a rhodolith bed composed of non-nucleated, unattached growths of branching, twig-like coralline algae (Basso et al., 2015). Recent maërl is known from the Mediterranean Sea (Basso, 1998; Basso et al., 2017), Portugal and Northern Spain (Peña and Bárbara, 2008; Pardo et al., 2014), the western coasts of Scotland, Ireland, Northern Ireland
(Bosence, 1976; Birkett et al., 1998) and sub-Arctic regions of northern Norway (Freiwald and Henrich, 1994).

Most rhodolith beds ( $80 \%)$ in the Mediterranean Sea lay within the depth range of $30-75 \mathrm{~m}, \sim 18 \%$ formed below this interval, while those from shallower environments are uncommon (Basso et al., 2017). Shallow rhodolith beds ( $<25 \mathrm{~m}$ ) are located for instance in the northern Adriatic Sea and Kuriat Islands (Basso et al., 2017). Negligible sedimentation rates and distance from significant nutrient influx are considered as one of the common distribution features within the Mediterranean Sea (Basso et al., 2017). In contrary, accumulations of maërl on European coasts of the Atlantic Ocean are in depth ranges from intertidal (i.e. Ireland) to $60 \mathrm{~m}$ depth (Canary Islands; Bosence, 1976; Peña and Bárbara, 2008; Peña et al., 2011; Pardo et al., 2014).

Melobesioid coralline algae were dominant limestone-building corallines during the Badenian in the Central Paratethys (Schaleková, 1969, 1973; Pisera, 1985; Studencki, 1988; Zdražílková, 1988; Pisera and Studencki, 1989; Bucur and Filipescu, 1994; Hrabovský, 2013; Hrabovský et al., 2015; Chelaru and Bucur, 2016). A similar dominance is observed as well at the Devínska Kobyla localities, although the assemblage composition differs in some respects from published data. The most evident is the absence of Sporolithon spp. This genus was identified from the Lower Badenian of the Vývrat locality as well as from Upper Badenian sites such as Sandberg (Schaleková, 1969). Unlike in the Upper Badenian, the dominant melobesioids are accompanied by Sporolithon - a common and diverse assemblage component at the Lower Badenian sites (Studencki, 1988; Pisera and Studencki, 1989; Hrabovský et al., 2015; Chelaru and Bucur, 2016).

The absence of Sporolithon in the material studied, along with the dominance of the Melobesioideae subfamily and the subordinate amounts of Lithophylloideae and Mastophoroideae (sensu Aguirre et al., 2000) indicate the middle to low latitude warm temperate zone. Moreover, the assemblage identified reflects cooling after the Mi3b event (Gradstein et al., 2012) at the Lower-Upper Badenian boundary, affecting benthic assemblages in the Central Paratethys (Pisera, 1996; Harzhauser and Piller, 2007).

\section{PALAEOENVIRONMENTAL RECONSTRUCTION}

Lower sequence (0- 20 m above the base of the composite profile) - marine environment. The sediment of the lower part of the sequence (0-6 $\mathrm{m}$ above the base of the composite profile) was deposited in a sublittoral environment under the influence of bottom currents, waves, and storms. Water dynamics was insufficient to wash away all the carbonate mud or to sort clasts. Sudden vertical changes in grain size indicate changes in dynamics, probably caused by occasional severe storms. During these events, coarse sediment was transported to the deeper part of the shelf. This is also documented by the occasional input of fragmented echinoids and coralline algae from the shallower zone.

The hybrid sand, rich in carbonate and siliciclastic fragments, was derived from the coastal cliffs formed by Mesozoic carbonates (Triassic limestone and dolomite and Jurassic breccia with dolomite matrix of the Devín Unit; Polák et al., 2011a, b). Weathered Triassic quartzite eroded from the mainland areas by rain and rivers is also an important deposit component. Paleozoic material (phyllites and granitoids, Permian conglomerates and porphyroids; Wessely, 2006; Polák et al., 2011a, b) was transported from the east, possibly by lateral coastal currents (Figs. 1 and 10). 
A water depth of 20 to $30 \mathrm{~m}$ is estimated from benthic foraminifers, algae and sedimentary characters. Both rhodoliths and seagrass suggest accumulation within the photic zone. However, the seagrass present, implied from epiphytic foraminifera, could survive up to depths with light irradiance at a level of $11 \%$ of that at the sea surface (Duarte, 1991).

The sandy seabed covered with algae and seagrasses was populated by foraminifera and sea urchins, with a few serpulids, bryozoans and bivalves. The bottom was burrowed by crustaceans feeding on seagrass debris. The sediment was bioturbated by Callianassidae crustaceans (see Hyžný, 2010; Hyžný and Hudáčková, 2012); some burrows resemble those of the lobster genus Nephrops (Gingras et al., 2000). Cross-bedding (Fig. 11F; sample 1), cracks and burrows (Fig. 11E) inside the algal growths also point to bioturbation and wave action.

The algal limestone (6-9 $\mathrm{m}$ above the base of the composite profile) composed mostly of organic fragments (60-90\%) indicates temporary siliciclastic input cessation. The limestone originated on an underwater mound, where the water depth reached approximately 8 to $16 \mathrm{~m}$ (as inferred from the foraminifera). A mound top (Figs. $3 \mathrm{~A}$ and 12) documented in profile ( $7 \mathrm{~m}$ above the base of the composite profile) was built by a rhodolith bed (sensu Basso et al., 2015) similar to the maërl subtype (rhodalgal assemblage), which is composed of semi-consolidated algal fruticose protuberances, possibly from rhodoliths, with a small content of very fine siliciclastic material. A seabed covered by seagrasses and algae is implied from the presence of epiphytic foraminifera and algal hooked structures (Figs. 11C and 10G; sensu Sola et al., 2013).

Fluctuation of the clastic content in the limestone indicates lateral progradation of the mound. The mound slopes were covered by red algae accompanied by regular and irregular echinoids, foraminifers, bryozoans, bivalves and ostracods of the rhodechfor assemblage.

Towards its foot, the mound was inhabited by an abundance of serpulids, bryozoans and foraminifers (Ammonia parkinsoniana) pointing to a low-energy environment. Locally, the amount of hyaline foraminifers and ostracods increased. A fragment of multi-specific "boxwork" rhodolith, with a typically loose internal structure with frequent constructional voids, was identified in this interval. Such rhodoliths are common in environments where hydraulic energy is too low to move nodules, such as in the Tyrrhenian Sea at depths of $\sim 90 \mathrm{~m}$ (Basso, 1998). It is possible to find "boxwork" rhodoliths also in higher energy environments where bottom morphology provides protection from currents.

The overlying sediment (9-19 m above the base of the composite profile) originated under similar conditions and was composed of similar material as in the bottom part (0-6 m above the base of the composite profile). We assume a dynamic environment at water depths of 20 to $30 \mathrm{~m}$ influenced by rare storms triggering the transport of coarser material from the shallower zone. Lateral changes (14-18 $\mathrm{m}$ above the base of the composite profile; Fig. 3B-D) from a zone with winnowed coarser material (sample 17) to a zone of finer material with partially washed-out matrix (sample 18) were observed. Considering the composite profile length $(100 \mathrm{~m})$, this fact can imply a variable coastline morphology or a absolute distance of each part of the profile from the former coast (Fig. 3).

Sediments filling wedge-shaped fissures (16-19 m above the base of the composite profile) can be interpreted as clastic
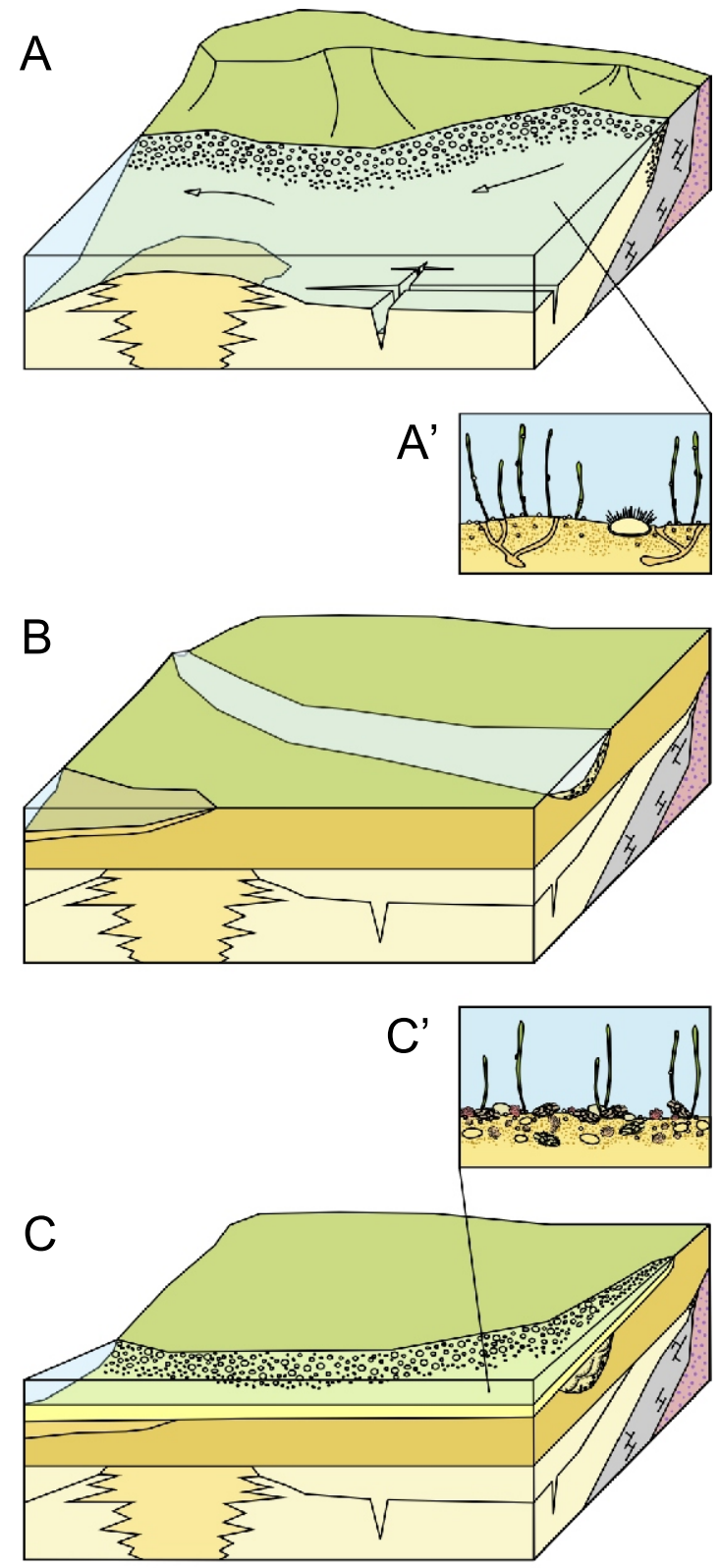

Triassic quartzite

Triassic and Jurassic carbonate

Sulline algae

rhodechfor, U. Badenian

(C) seagrass

regolith, U. Baden.-Sarmat.

viluty echinoids

bivalves

Y burrows

fuvial channel, U. Baden.-Sarmat.

.00 - foraminifers

lagoonal facies, U. Baden.-Sarmat.

$\sqrt{ }$ dykes

transgress. facies, U. Baden.-Sarmat.

$\sim$ currents

\section{Fig. 12. Block diagrams}

A, A' - Upper Badenian shallow-marine environment; B - Upper Badenian-Sarmatian lagoonal and terrestrial facies; C, C' Sarmatian marine transgressive facies 
dykes, which are one of the mass wasting indicators, possibly triggered by earthquakes.

Terrestrial clastic material forms 65 to $85 \%$ of the sediment. Variable amounts of fossils points to unstable environmental conditions. An echinofor skeletal assemblage with infaunal irregular echinoids (sensu Hayton et al., 1995) is identified in the interval within the profile (11-12 $\mathrm{m}$ above the base of the composite profile), where sea urchins prevail over coralline algae and bivalves. A facies change is reflected by the dominance of the red algae (55-75\%) over sea urchins and other fossils. This is typical for the rhodechfor assemblage (12-18 $\mathrm{m}$ above the base of the composite profile) associated with seagrasses and crustacean dwellers.

Sediment occurring 18.1-18.3 $\mathrm{m}$ above the base of the composite profile (sample 19) with a large amount of praline rhodoliths, mastophoroidal incrustations, and colonies of bryozoan and serpulids (up to $3 \mathrm{~cm}$ ) encrusted by red algae, were possibly derived from the nearby bioherm formed in heated water. An increased amount of porcellaneous foraminifers, e.g. Borelis melo (17-19 $\mathrm{m}$ above the base of the composite profile), may indicate patch reefs or a hypersaline lagoon in the vicinity. This horizon can be correlated with the layer observed in quarries between the Pfaffenberg and Hundsheimerberg in the Hainburg hills (D. Pivko, personal observation). Therefore, we can assume similar environmental conditions in these currently distinct areas (8 km apart) along the former archipelago coastline during the Serravallian (Leitha Limestone; Wessely, 1961).

The overlying fine sandy sediment $(\sim 19-20 \mathrm{~m}$ above the base of the composite profile), with a large proportion of micrite matrix, refers to a quiet shallow-marine rhodechfor environment with a bottom covered by seagrass. Possible deepening (water depth around $30 \mathrm{~m}$ ) is documented by an echinofor assemblage (20 $\mathrm{m}$ above the base of the composite profile; sample 24). A fining-upwards pattern and increase in quartz content (up to $35 \%$ ), derived from Triassic quartzites and Permian conglomerates, document a possible rise in sea level (Figs. 1 and 12).

Middle sequence ( 20-22 $\mathrm{m}$ above the base of the composite profile) - terrestrial environment. Sands and gravels above fine marine sandstones show conspicuous signs of terrestrial sedimentation, such as barren sediment, palaeosoil features, fluvial channel deposits and the absence of calcite cement. Terrestrial sediment was deposited directly on the sublittoral sands, which originated in a water depth of $\sim 30 \mathrm{~m}$. Therefore, the relative sea level fall was at least tens of metres. Lithified sandstone with diagenetic calcite cement together with the lack of shallower (eulittoral) deposits, indicate deep erosion prior to the deposition of the terrestrial sediment (Figs. 3F, 8D and 12).

This sequence begins with sandy regolith $(40 \mathrm{~cm})$ and consists of angular siliciclastic material showing signs of redeposition inferred from the different material composition as in the underlying sandstone. From the presence of framboidal pyrite, a reducing environment in the bottom part of the regolith and upper part of the sandstone is inferred. This may point to conditions of a wet meadow environment. The pyrite was subsequently weathered to goethite, which causes the rusty colour of the rock.

The upper part of the regolith layer contains loose white calcrete laminae intercalations which reflect stages of soil origination. The calcrete precipitated from calcareous water percolating through the sediment with the participation of the roots of plants or fungal fibres (identified as Microcodium). Traces of framboidal pyrite and skelsepic fabric characteristic of soil processes are present in the calcrete intercalations. The calcrete laminae were folded and segmented during uneven compaction.
Above the regolith, a river channel deposit with a maximum thickness of $120 \mathrm{~cm}$ was found (Figs. 3F and 8D). Gradual filling of the general NE-SW oriented channel incision contains siliciclastic material derived from the exposed Malé Karpaty Mts. The profile begins with residual gravel followed by slightly distinct a trough to planar cross-bedding. The deposits contain grey and rusty streaks of diffuse precipitations of iron oxyhydroxides due to the redox conditions in the river sediment, with periodic flooding and drying. It can be identified as a stagnosol (Świtoniak and Charzyński, 2014).

Upper sequence ( 22-27 $\mathrm{m}$ above the base of the composite profile) - marine environment. A transgression from the west led to partial erosion of the fluvial deposits and covered them with marine sand (up to $30 \mathrm{~cm}$ thick) deposited in a low energy hypersaline lagoonal environment. The sediment mostly comprised redeposited siliciclastic material - winnowed regolith and calcrete. Environmental changes are reflected in variable fossil associations. There is a general absence of red algae, abundance of ostracods and crustacean burrows.

The following transgression sequence, with a thickness of $5 \mathrm{~m}$, is formed by pebble conglomerates. The clasts predominantly comprise rock fragments (some encrusted), with subordinate oysters, other bivalves and rhodoliths deposited by the surf, which probably broke through a barrier of the lagoon.

Very dynamic sedimentation was interrupted several times by more quiet deposition. Lower-energy episodes within the dynamic sedimentation are documented by finer-grained sediment with a predominance of bioclasts, probably reworked maërl, which was formed in a protected environment.

A recorded sea level drop followed by a rise can be correlated with the Ser 3 sequence boundary of Hardenbol et al. (1998) which was documented in the Late Badenian to Early Sarmatian transitional foraminiferal assemblages (20-22 m above the base of the composite profile). Erosion associated with this boundary was also discussed by Harzhauser and Piller (2004a, b, 2007), Kováč et al. (2007), Piller at al. (2007), Gebhardt at al. (2009) and Hohenegger et al. (2014). The coarsest transgressive clastic deposits in the profile resemble a similar succession observed in the quarries noted near Hundsheim, where marine sedimentation of finer deposits took place, with large bryozoan nodules and algal rhodoliths gave way to deposition of conglomerates from the Sarmatian age with an abundant Badenian fauna (Wessely, 1961). Badenian fluvial and limnic deposits have been described in the Vienna Basin (Wessely, 2006).

A recent calcrete ( $\sim 27 \mathrm{~m}$ above the base of the composite profile) with needle-shaped calcite and remains of plant tissues was identified in the uppermost part of the log, located just below the soil layer.

\section{CONCLUSIONS}

The "Medieval Quarry" located near the village of Devín, with rich fossil assemblages composed mostly of coralline algae and foraminifers, represents a good example of organodetrital carbonate and siliciclastic sedimentation. Its sedimentological and petrographical features allowed interpretations of its age and palaeoenvironment.

Based on the benthic foraminiferal assemblages, the strata were assigned to the Serravallian - Late Badenian and Sarmatian ages of the Central Paratethys with a connection to the Eastern Paratethys, documented by the presence of the Titanoderma pustulatum (Lamouroux) Nägeli. 
Late Badenian sedimentation was dominated by coarsegrained sandy carbonate and siliciclastic deposits derived from the crystalline rocks and Mesozoic sedimentary cover of the Malé Karpaty Mts., which point to uplifted position of the source area. Still active tectonic movement in the region is documented by the presence of clastic dikes and normal faults. The deposits studied are thought to have accumulated mostly in the sublittoral zone with a maximum depth of $30 \mathrm{~m}$ under the influence of waves and currents in a lagoon or shelf in a warm temperate climatic zone where melobesioids were associated with mastophoroids and lithophylloids. Changing water dynamics enabled the development of maërl, pralines and "boxwork" rhodoliths together with seagrass beds in the vicinity. Occasional storm events and wave activity disturbed the rhodoliths and encrustations which resulted in significant debris production. Three different types of organodetrital sediments were distinguished within the Badenian succession. A rhodechfor type is composed mostly of coralline algae (Mesophyllum, Lithothamnion, Spongites and Lithophyllum), benthic foraminifers (Elphidium crispum, Neoconorbina terquemi, Miniacina sp., Borelis melo), echinoids (cidaroid, diadematoid and spatangoid groups) and bryozoans. It developed on a seabed covered partly by seagrasses and bioherm slopes. Temporary shallowing of the environment is documented by a rhodalgal se- quence with typical maërl facies. This is followed by alternations of rhodechfor and rare echinofor facies. Lateral alternation at a small spatial scale reflects a diverse sedimentary environment. Sedimentation proceeded on the well-oxygenated seabed which was bioturbated by crustaceans and interrupted by low-oxygen episodes. The rhodechfor and echinofor environments are described from the Central Paratethys realm for the first time.

Fluvial and terrestrial sediments represented by regolith, palaeosoil and channel body deposits rest discordantly on top of the marine deposits.

The topmost sequence characterized by a transgressive facies is formed of coarsest pebbly deposits. Based on the benthic foraminifera association, a Sarmatian age this unit is inferred.

Acknowledgements. This work was supported by the Slovak Research and Development Agency under the contract APVV 14-0118; APVV 15-0575. The authors wish to express their gratitude to Assoc. Prof. J. Čurlík, Dr. M. Hyžný, Dr. K. Zágoršek, Dr. E. Halásová, Dr. M. Šujan, Dr. S. Rybár, and anonymous reviewers for useful comments, consultation and advice.

\section{REFERENCES}

Aguirre, J., Riding, R., Braga, J.C., 2000. Diversity of coralline red algae: origination and extinction patterns from the Early Cretaceous to the Pleistocene. Paleobiology, 26: 651-667.

Baráth, I., 1992. Upper Badenian reef complex on eastern margin of the Vienna Basin (in Slovak with English summary). Knihovnička zemního plynu a nafty, 15: 177-197.

Baráth, I., Nagy, A., Kováč, M., 1994. Sandberg Member - Upper Badenian marginal sediments of the eastern edge of the Vienna Basin. Geologické práce, Správy, 99: 59-66.

Bassi, D., Braga, J.C., Iryu, Y., 2009. Palaeobiogeographic patterns of a persistent monophyletic lineage: Lithophyllum pustulatum species group (Corallinaceae, Corallinales, Rhodophyta). Palaeogeography, Palaeoclimatology, Palaeoecology, 284: 237-245.

Basso, D., 1998. Deep rhodolith distribution in the Pontian Islands, Italy: a model for the paleoecology of a temperate sea. Palaeogeography, Palaeoclimatology, Palaeoecology, 137: 173-187.

Basso, D., Tomaselli, V., 1994. Palaeoecological potentiality of rhodoliths: a Mediterranean case history. Bollettino della Societa Paleontologica Italiana, 33: 17-28.

Basso, D., Nalin, R., Nelson, C.S., 2009. Shallow water Sporolithon rhodoliths from North Island (New Zealand). Palaios, 24: 92-103.

Basso, D., Babbini, L., Kaleb, S., Bracchi, V.A., Falace, A., 2015 Monitoring deep Mediterranean rhodolith beds. Aquatic Conservation: Marine and Freshwater Ecosystems, 26: 549-561.

Basso, D., Babbini, L., Ramos-Esplá, A.A., Salomidi, M., 2017. Mediterranean rhodolith beds. Coastal Research Library, 15 281-298.

Berkeley, A., Perry, C.T., Smithers, S.G., 2009. Taphonomic signatures and patterns of test degradation on tropical, intertidal benthic foraminifera. Marine Micropaleontology, 73: 148-163.

Birkett, D.A., Maggs, C.A., Dring, M.J., 1998. Maerl (volume V). An overview of dynamic and sensitivity characteristics for conservation management of marine SACs. Scottish Association for Marine Science.
Bitner, M.A., Zágoršek, K., Halásová, E., Hudáčková, N., Jamrich, M., 2014. Brachiopods and bryozoans from the Sandberg section (Vienna Basin, Central Paratethys) and their significance for environmental interpretation of the Early Sarmatian (= Middle Miocene). Sea. Neues Jahrbuch für Geologie und Paläontologie Abhandlungen, 273: 207-219.

Boltovskoy, E., 1976. Distribution of recent foraminifera of the South American region. In: Foraminifera (eds. R.H. Hedley and C.G. Adams). Academic Press, London, 2: 171-236.

Boltovskoy, E., Wright, R., 1976. Recent Foraminifera. The Hague, W. Junk.

Bosence, D.W.J., 1976. Ecological studies on two unattached coralline algae from western Ireland. Paleontology, 19: 365-395.

Bosence, D.W.J., 1983. The occurrence and ecology of recent rhodoliths: a review. In: Coated grains (ed. T.M. Peryt): 225-242. Springer, Berlin.

Braga, J.C., Bosence, D.W.J., Steneck, R.S., 1993. New anatomical characters in fossil coralline algae and their taxonomic implications. Palaeontology, 36: 535-547.

Bucur, I., Filipescu, S., 1994. Middle Miocene red algae from the Transylvanian Basin (Romania). Beiträge zur Paläontologie, 19: $39-47$.

Carannante, G., Esteban, M., Milliman, J.D., Simone, L., 1988. Carbonate lithofacies as paleolatitude indicators: problems and limitations. Sedimentary Geology, 60: 333-346.

Chelaru, R., Bucur, I.I., 2016. The taxonomy of middle Miocene red algae from Gârbova de Sus Formation (Transylvanian Basin, Romania). Carnets de Geologie, 16: 307-336.

Cherif, O.H., Al-Rifaiy, I.A., Al-Ghadban, A.N., 1997. Distribution of Foraminifera in the Arabian Gulf. Micropaleontology, 43: 253-280.

Cicha, I., Zapletalová, I., Molčíková, V., Brzobohatý, R., 1983. Stratigraphical range of Eggenburgian-Badenian foraminifera in West Carpathian basins. Miscellanea Micropaleontologica, 18: $99-144$ 
Cicha, I., Baldi, T., Brzobohatý, R., Bůžek, Č., Čtyroká, J., Fejfar, O., Gabrielová, N., Holý, F., Jiříček, R., Knobloch, E., Kvaček, Z., Lehotayová, R., Molčíková, V., Němejc, F., Planderová, E., Řeháková, Z., Seneš, J., Sitár, V., Slávik, J., Steininger, F., Švagrovský, J., Váňová, M., Vass, D., Zapletalová, I., 1975. Biozonal Division of the Upper Tertiary Basins of the Eastern Alps and West Carpathians. I.U.G.S. Proccedings of the VI Congress, Bratislava.

Cicha, I., Rögl, F., Rupp, Ch., Čtyroká, J., 1998. Oligocene-Miocene Foraminifera of the Central Paratethys. Abhandlungen der Senckenbergischen Naturforschenden Gesellschaft, 549: $1-325$.

Dickinson, W.R., Beard, L.S., Brakenridge, G.R., Erjavec, J.L., Ferguson, R.C., Inman, K.F., Knepp, R.A., Lindberg, F.A., Ryberg, P.T., 1983. Provenance of North American Phanerozoic sandstones in relation to tectonic setting. GSA Bulletin, 94: 222-235.

Duarte, C.M., 1991. Seagrass depth limits. Aquatic Botany, 40: 363-377.

Dunham, R.J., 1962. Classification of carbonate rocks according to depositional texture. AAPG Memoir, 1: 108-121.

Embry, A.F., Klovan, J.S., 1971. A Late Devonian reef tract on northeastern Banks Island, N.W.T. Bulletin of Canadian Petroleum Geology, 4: 730-781.

Filipescu, S., 2004. Anomalinoides dividens bioevent at the Badenian/Sarmatian boundary - a response to paleogeographic and paleoenvironmental changes. Studia Universitatis Babes-Bolyay, Geologia, 49: 21-26.

Filipescu, S., Miclea, A., Gross, M., Harzhauser, M., Zágoršek, K., Jipa, C., 2014. Early Sarmatian paleoenvironments in the easternmost Pannonian Basin (Borod Depression, Romania) revealed by the micropaleontological data. Geologica Carpathica, 65: 67-81.

Flügel, E., 2010. Microfacies of Carbonate Rocks. Analysis, Interpretation and Application. Second edition. Springer, Berlin.

Folk, R.L., 1962. Spectral subdivision of limestone types. AAPG Memoir, 1: 62-84.

Földes, A., 1960. Neogene geological settings of the Devínska Kobyla area (in Slovak). Diploma thesis.

Fordinál, K., Král', J., Harčová, M., Čech, P., Zieliński, G., Nagy, A., 2014. ${ }^{87} \mathrm{Sr} /{ }^{86} \mathrm{Sr}, \delta^{13} \mathrm{C}$ and $\delta^{18} \mathrm{O}$ in mollusc fossil shells from marine, brackish and freshwater environments (in Slovak with English summary). Mineralia Slovaca, 46: 23-44.

Freiwald, A., Henrich, R., 1994. Reefal coralline algal buildups within the Arctic Circle: morphology and sedimentary dynamics under extreme environmental seasonality. Sedimentology, 41: 963-984.

Gaglianone, G. Frezza, V., Brandano, M., 2015. Sedimentary facies and foraminiferal assemblages from Posidonia oceanica meadows of western Mediterranean Sea. PeerJ PrePrints 3:e1373 https://doi.org/10.7287/peerj.preprints.1125v1

Gebhardt, H., Zorn, I., Roetzel, R., 2009. The initial phase of the early Sarmatian (Middle Miocene) transgression. Foraminiferal and ostracod assemblages from an incised valley fill in the Molasse Basin of Lower Austria. Austrian Journal of Earth Sciences, 102: 100-119.

Gingras, M.K., Hubbard, S.M., Pemberton, S.G., Saunders, T., 2000. The significance of Pleistocene Psilonichnus at Willapa Bay, Washington. Palaios, 15: 142-151.

Gonera, M., 2013. Globorotaliid intervals of the sub-evaporite Badenian (Middle Miocene) in the Upper Silesia Basin (Central Paratethys, Poland). Geological Quarterly, 57 (4): 757-768.

Górka, M., Studencka, B., Jasionowski, M., Hara, U., Wysocka, A., Poberezhskyy, A., 2012. The Medobory Hills (Ukraine): Middle Miocene reef systems in the Paratethys, their biological diversity and lithofacies. Biuletyn Państwowego Instytutu Geologicznego, 449: 147-174.

Görög, Á., 1992. Sarmatian foraminifera of the Zsámbék Basin, Hungary. Annales Universitatis Scientiarum Budapestinensis, sectio Geologica, 29: 31-153.
Gradstein, F.M., Ogg, J.G., Schmitz, M.D., Ogg, G.M., 2012. The Geologic Time Scale 2012. Elsevier, Amsterdam.

Grill, R., 1941. Stratigraphische Untersuchungen mit Hilfe von Mikrofaunen im Wiener Becken und den benachbarten Molasse - Anteilen. Oel und Kohle, 37: 595-602.

Grill, R., 1943. Über mikropaläontologische Gliederungsmöglichkeiten im Miozän des Wiener Becken. Mitteilungen der Reichsamts für Bodenforschung, 6: 33-44.

Hammer, R., Harper, D.A.T., Ryan, P.D., 2001. PAST: Paleontological statistics software package for education and data analysis. Palaeontologia Electronica, 4: 1-9.

Hardenbol, J., Thierry, J., Farley, M.B., Jacquin, T., Graciansky, P.C., Vail, P.R., 1998. Mesozoic and Cenozoic sequence chronostratigraphic framework of European Basins. SEPM Special Publication, 60: 3-13.

Harzhauser, M., Piller, W.E., 2004a. Integrated stratigraphy of the Sarmatian (Upper Middle Miocene) in the western Central Paratethys. Stratigraphy, 1: 65-86.

Harzhauser, M., Piller, W.E., 2004b. The Early Sarmatian - hidden seesaw changes. Courier Forschungsinstitut Senckenberg, 246: 89-111.

Harzhauser, M., Piller, W.E., 2007. Benchmark data of a changing sea - Palaeogeography, palaeobiogeography and events in the Central Paratethys during the Miocene. Palaeogeography, Palaeoclimatology, Palaeoecology, 253: 8-21.

Hayton, S., Nelson, C.S., Hood, S.D., 1995. A skeletal assemblage classification system for non-tropical carbonate deposits based on New Zealand Cenozoic limestones. Sedimentary Geology, 100: 123-141.

Hohenegger, J., 2005. Estimation of environmental paleogradient values based on presence/absence data: a case study using benthic foraminifera for paleodepth estimation. Palaeogeography, Palaeoclimatology, Palaeoecology, 217: 115-130.

Hohenegger, J., Andersen, N., Báldi, K., Ćorić, S., Pervesler, P., Rupp, Ch., Wagreich, M., 2008. Paleoenvironment of the Early Badenian (Middle Miocene) in the southern Vienna Basin (Austria) - multivariate analysis of the Baden-Sooss section. Geologica Carpathica, 59: 461-487.

Hohenegger, J., Ćorić, S., Wagreich, M., 2014. Timing of the Middle Miocene Badenian Stage of the Central Paratethys. Geologica Carpathica, 65: 55-66.

Holbourn, A., Kuhnt, W., Clemens, S.C., Prell, W.L., Andersen, N., 2013. Middle to late Miocene stepwise climate cooling: Evidence from a high-resolution deep water isotope curve spanning 8 million years. Paleoceanography, 28: 1-12.

Holcová, K., 1997. Can detailed sampling and taphonomical analysis of foraminiferal assemblages offer new data for paleoecological interpretations? Revue de Micropaléontologie, 40: 313-329.

Holcová, K., 1999. Postmortem transport and resedimentation of foraminiferal tests: relations to cyclical changes of foraminiferal assemblages. Palaeogeography, Palaeoclimatology, Palaeoecology, 145: 157-182.

Holec, P., Sabol, M., 1996. The Tertiary Vertebrates from Devínska Kobyla (in Slovak). Mineralia Slovaca, 28: 519-522.

Hrabovský, J., 2013. Non-geniculate coralline algae (Corallinales, Sporolithales, Rhodophyta) from lithothamnion limestones of the locality Vrchná Hora at the town of Stupava (Vienna Basin, Slovakia) (in Slovak with English summary). Mineralia Slovaca, 45: 23-34.

Hrabovský, J., Basso, D., Doláková, N., 2015. Diagnostic characters in fossil coralline algae (Corallinophycidae: Rhodophyta) from the Miocene of southern Moravia (Carpathian Foredeep, Czech Republic). Journal of Systematic Palaeontology, 14: 499-525.

Hudáčková, N., Zlinská, A., 2010. Paleoenvironmental interpretation of Lower Sarmatian sediments from Malacky and Pernek surroundings (Slovak part of the Vienna Basin) (in Slovak with English summary). Mineralia Slovaca, 42: 419-428.

Hudáčková, N., Halásová, E., Fordinál, K., Sabol, M., Joniak, P., Král', J., 2003. Biostratigraphy and radiometric dating in the Vi- 
enna Basin Neogene (Slovak part). Slovak Geological Magazine, 9: 233-236.

Hyžný, M., 2010. Revision of the Eocene decapod crustaceans deposited in the Liptov museum Čierny Orol (Liptovský Mikuláš, Slovakia). Acta Geologica Slovaca, 2: 117-122.

Hyžný, M., Hudáčková, N., 2012. Redescription of two ghost shrimps (Decapoda: Axiidea: Callianassidae) from the Middle Miocene of the Central Paratethys: systematics, intraspecific variation, and in situ preservation. Zootaxa, 3210: 1-25.

Hyžný, M., Hudáčková, N., Biskupič, R., Rybár, S., Fuksi, T., Halásová, E., Zágoršek, K., Jamrich, M., Ledvák, P., 2012 Devínska Kobyla - a window into the Middle Miocene shallow-water marine environments of the Central Paratethys (Vienna Basin, Slovakia). Acta Geologica Slovaca, 4: 95-111.

Jamrich, M., Halásová, E., 2010. Development of calcareous nannofossil associations of Vienna Basin as a reflection of paleoenvironmental changes during Upper Badenian (Devínska Nová Ves brickyard) (in Slovak with English summary). Acta Geologica Slovaca, 2: 123-140.

Kato, A., Baba, M., Suda, S., 2011. Revision of the Mastophoroideae (Corallinales, Rhodophyta) and polyphyly in nongeniculate species widely distributed on Pacific coral reefs. Journal of Phycology, 47: 662-672.

Knörich, A.C., Mutti, M., 2003. Controls of facies and sediment composition on the diagenetic pathway of shallow-water Heterozoan carbonates: the Oligocene of the Maltese Islands. International Journal of Earth Sciences, 92: 494-510.

Koubová, I., Hudáčková, N., 2010. Foraminiferal successions in the shallow water Sarmatian sediments from the MZ 93 borehole (Vienna Basin, Slovak part). Acta Geologica Slovaca, 2: 47-58.

Koutek, J., Zoubek, V., 1936. Report on geological studies and mapping in the vicinity of Bratislava (in Czech). Vestník Státního geologického ústavu Československé republiky, 12: 67-76.

Kováč, M., Andreyeva-Grigorovich, A., Bajraktarević, Z., Brzobohatý, R., Filipescu, S., Fodor, L., Harzhauser, M., Nagymarosy, A., Oszczypko, N., Pavelić, D., Rögl, F., Saftić, B., Sliva, L'., Studencka, B., 2007. Badenian evolution of the Central Paratethys Sea: paleogeography, climate and eustatic sea-level changes. Geologica Carpathica, 58: 579-606.

Kováčová, P., Hudáčková, N., 2009. Late Badenian foraminifers from the Vienna Basin (Central Paratethys): stable isotope study and paleoecological implications. Geologica Carpathica, 60: $59-70$.

Kroh, A., Harzhauser, M., 1999. An echinoderm fauna from the Lower Miocene of Austria: paleoecology and implications for Central Paratethys paleobiogeography. Annalen des Naturhistorischen Museums in Wien, 101: 145-191.

Kroh, A., Nebelsick, J.H., 2010. Echinoderms and Oligo-Miocene carbonate systems: potential applications in sedimentology and environmental reconstruction. IAS Special Publications, 42: 201-228.

Kvaček, Z., Kováč, M., Kovar-Eder, J., Doláková, N., Jechorek, H., Parashiv, V., Kováčová, M., Sliva, L'., 2006. Miocene evolution of landscape and vegetation in the Central Paratethys. Geologica Carpathica, 57: 295-310.

Langer, M., 1993. Epiphytic foraminifera. Marine Micropaleontology, 20: 235-265.

Loeblich, A.R., Tappan, H., 1992. Present status of foraminiferal classification. In: Studies in Benthic Foraminifera (eds. Y Takayanagi and T. Saito): 93-102. Tokai University Press.

Łuczkowska, E., 1998. Marine Miocene deposits of the Paratethys in Poland. Abhandlungen der Senckenbergischen Naturforschenden Gesellschaft, 549: 28-34.

Madarás, J., ed., 2014. Sandberg - Pajštún geopark guide (in Slovak). ŠGÚDŠ, Bratislava.

Mišík, M., 1997. Geological structure of Devínska Kobyla hill (in Slovak with English summary). In: Flora, geology and paleontology of Devínska Kobyla hill (eds. V. Feráková and E. Kocianová): 11-18. APOP, Litera, Bratislava.
Murray, J.W., 1973. Distribution and Ecology of Benthic Foraminiferids. Heinemann Educational Books, London.

Murray, J.W., 2006. Ecology and Applications of Benthic Foraminifera. Cambridge University Press, New York.

Papp, A., 1959. Tertiar. 1. Teil. Grundzüge regionaler Stratigraphie. Handbuch der Stratigraphischen Geologie, Stuttgart, 3: 1-411.

Pardo, C., Lopez, L., Peña, V., Hernández-Kantún, J., Le Gall, L., Bárbara, I., Barriero, R., 2014. A multilocus species delimination reveals a striking number of species of coralline algae forming maerl in the OSPAR maritime area. PLoS ONE, 9(8), 104073. doi:10.1371/journal.pone.0104073.

Peña, V., Bárbara, I., 2008. Maerl community in the northwestern Iberian Peninsula: a review of floristic studies and long-term changes. Aquatic Conservation: Marine and Freshwater Ecosystems, 18: 339-366.

Peña, V., Adey, W.H., Rodríguez, R.R., Jung, M.Y., Carrillo, J.A., Choi, H.G., Bárbara, I. 2011. Mesophyllum sphaericum sp. nov. (Corallinales, Rhodophyta): a new maërl forming species from the northeast Atlantic. Journal of Phycology, 47: 911-927.

Pergent, G., Bellan-Santini, D., Bellan, G., Bitar, G., Harmelin, J.G., eds., 2007. Manuel d'interprétation des types d'habitats marins pour la sélection des sites í inclure dans les inventaires nationaux de sites naturels d'intéręt pour la Conservation. PNUE-PAM-CAR/ASP publ., Tunis.

Peryt, D., 2013. Foraminiferal record of marine transgression during deposition of the Middle Miocene Badenian evaporites in Central Paratethys (Borków section, Polish Carpathian Foredeep). Terra Nova, 25: 298-306.

Peryt, D., Jasionowski, M., 2012. Sarmatian foraminiferal assemblages of cavern fillings in the Badenian reefs of Medobory (Polupanivka, Western Ukraine). Biuletyn Państwowego Instytutu Geologicznego, 449: 175-184.

Pérès, J.M., Picard, J., 1964. Nouveau manuel de bionomie benthique de la Méditerranée. Recueil des Travaux de la Station Marine d'Endoume, 31: 1-137.

Piller, W.E., Harzhauser, M., Mandić, O., 2007. Miocene Central Paratethys stratigraphy - current status and future directions. Stratigraphy, 4: 151-168.

Pisera, A., 1985. Paleoecology and lithogenesis of the Middle Miocene (Badenian) algal-vermetid reefs from the Roztocze Hills, south-eastern Poland. Acta Geologica Polonica, 35: 89-155.

Pisera, A., 1996. Miocene reefs of the Paratethys: a review. SEPM Concepts in Sedimentology and Paleontology , 5: 1-398.

Pisera, A., Studencki, W., 1989. Middle Miocene rhodoliths from the Korytnica Basin (Southern Poland): environmental significance and paleontology. Acta Palaeontologica Polonica, 34: 179-209.

Pivko, D., 2011. Historical quarry of Leitha limestone in Devin near Bratislava (in Slovak with German summary). Proceedings from conference Forum Urbes Medii Aevi VII, Archaia, Brno.

Polák, M., ed., Plašienka, D., Kohút, M., Putiš, M., Bezák, V., Filo, I., Olšavský, M., Havrila, M., Buček, S., Maglay, J., Elečko, M., Fordinál, K., Nagy, A., Hraško, L'., Németh, Z., Ivanička, J., Broska, I., 2011a. Geological map of Malé Karpaty Mts. in scale 1:50,000 (in Slovak). ŠGÚDŠ, Bratislava.

Polák, M., Plašienka, D., Kohút, M., Putiš, M., Bezák, V., Maglay, J., Olšavský, M., Havrila, M., Buček, S., Elečko, M., Fordinál, K., Nagy, A., Hraško, L'., Németh, Z., Liščák, P., Slavkay, M., Kubeš, P., 2011b. Explanatory notes to Geological map of Malé Karpaty Mts. in scale 1:50,000 (in Slovak with English summary). ŠGÚDŠ, Bratislava.

Pomoni-Papaioannou, F., Drinia, H., Dermitzakis, M.D., 2002. Neogene non-tropical carbonate sedimentation in a warm temperate biogeographic province (Rethymnon Formation, Eastern Crete, Greece). Sedimentary Geology, 154: 147-157.

Popescu, Gh., 1995. Contribution to the knowledge of Sarmatian foraminifera of Romania. Romanian Journal of Paleontology, 75: 85-98.

Rösler, A., Perfectti, F., Peńa, V., Braga, J.C., Gabrielson, P., 2016. Phylogenetic relationships of corallinaceae (Corallinales, 
Rhodophyta): taxonomic implications for reef-building corallines. Journal of Phycology, 52: 412-431.

Schaleková, A., 1969. Contribution to the knowledge of red algae in the Leitha Limestone at the locality Sandberg near Devínska Nová Ves (southwestern Slovakia). Acta geologica et geographica Universitatis Comenianae, Geologica, 18: 93-102.

Schaleková, A., 1973. Oberbadenische corallinaceen aus dem Steinbruch Rohožník-Vajarská an dem Westhang der Kleinen Karpaten. Acta geologica et geographica Universitatis Comenianae, Geologica, 26: 211-227.

Sola, F., Braga, J.C., Aguirre, J., 2013. Hooked and tubular coralline algae indicate seagrass beds associated to Mediterranean Messinian reefs (Poniente Basin, Almería, SE Spain). Palaeogeography, Palaeoclimatology, Palaeoecology, 374: 218-229.

Spezzaferri, S., Rüggeberg, A., Stalder, C., Margreth, S., 2013 Benthic foraminifera from Norwegian cold-water coral reefs. Journal of Foraminiferal Research, 43: 21-39.

Studencki, W., 1988. Red algae from the Pińczów limestones (Middle Miocene, Świętokrzyskie Mountains, Poland). Palaeontologica Polonica, 33: 3-57.

Studencki, W., 1999. Red-algal limestones in the Middle Miocene of the Carpathian Foredeep in Poland: facies variability and palaeoclimatic implications. Geological Quarterly, 43 (4): 395-404.

Švagrovský, J., 1978. Faciostratotypus Devínska Nová Ves Sandberg. In: Chronostratigraphie und neostratotypen, Miozän der Zentralen Paratethys, M4 Badenien (eds. A. Papp, I. Cicha, J. Seneš and F. Steininger): 188-193. VEDA, Bratislava.

Świtoniak, M., Charzyński, P., eds., 2014. Soil Sequences Atlas. Nicolaus Copernicus University Press, Toruń.

Thissen, J.M., Langer, M.R., 2014. Foraminifera as ecosystem engineers: A case study from the Zanzibar Archipelago (Tanza- nia). Conference: International Symposium on Foraminifera 2014, at Concepción, Chile, Conference paper.

Tóth, E., Görög, Á., Lécuyer, C., Moissette, P., Balter, V., Monostori, M., 2010. Palaeoenvironmental reconstruction of the Sarmatian (Middle Miocene) Central Paratethys based on palaeontological and geochemical analyses of foraminifera, ostracods, gastropods and rodents. Geological Magazine, 147: 299-314.

Vass, D., 2002. Lithostratigraphy of Western Carpathians: Neogene and Buda Paleogene (in Slovak with English summary). ŠGÚDŠ, Bratislava.

Wessely, G., 1961. Geologie der Hainburger Berge. Jahrbuch der Geologischen Bundesanstalt, 104: 273-349.

Wessely, G., 2006. Wiener Becken. In: Geologie von Niederösterreich (eds. G. Wessely, H. Peresson, R. Sauer, I. Draxler, G. Gangl, P. Gottschling, M. Heinrich, T. Hofmann, W. Lenhardt, A. Matura and R. Pavuza): 189-226. Geologische Bundesanstalt, Wien.

Westphal, H., 1998. Carbonate platform slopes - a record of changing conditions. The Pliocene of the Bahamas. Lecture Notes in Earth Science, 75: 1-197.

Woelkerling, W.M.J., Irvine, L.M., Harvey, A.S., 1993. Growth-forms in non-geniculate coralline red algae (Corallinales, Rhodophyta). Australian Systematic Botany, 6: 277-293.

Zdražilková, N., 1988. Corallinaceae in the lower Badenian of the Carpathian Foredeep (in Czech). Časopis pro Mineralogii a Geologii, 33: 187-196.

Zuffa, G.G., 1980. Hybrid arenites: their composition and classification. Journal of Sedimentary Research, 50: 21-29. 